المجله (11) العده (1) (1) (1)

2019 لسنة

دور حوكمة الشركاتفي حماية حقوق المستثمرين/ دراسة تحليلية في سوق العراق للاوراق المالية http://dx.doi.org/10.28936/jmracpc11.1.2019.(12)

شذى عبد الحسين جبر ا، فذاء عدنان عبيد2

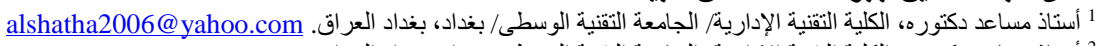

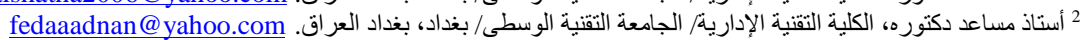

ينطلق البحث الحالي من مشكلة رئيسية تتمثل في ان ضعف دور الافصاح عن المعلومات الخاصة بالشركات في

الخلاصة

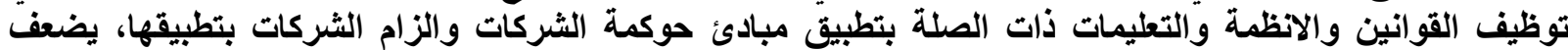

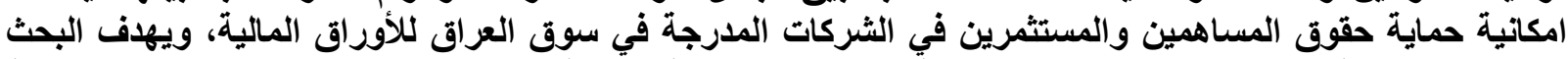

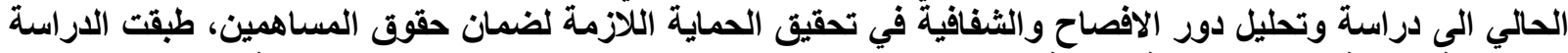

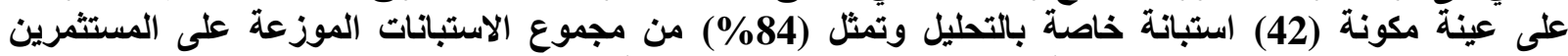

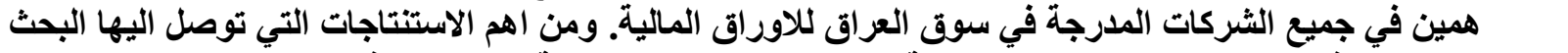

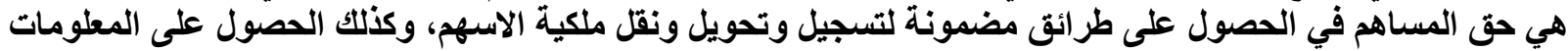

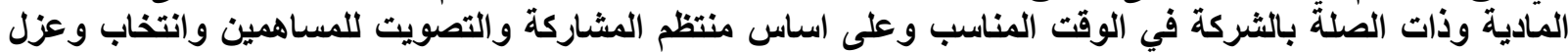

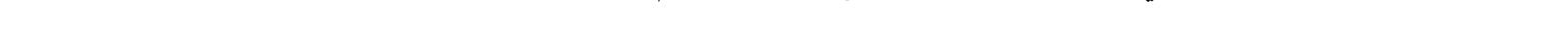

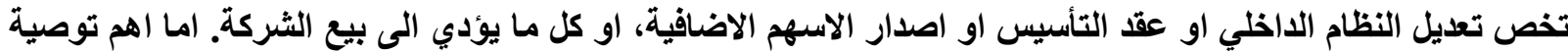
فهي ضرورة الزام الثركات بإعداد التقارير المالية الفصلية والنصف سنوية بالاضافة التى التئية التقارير السنوية.

الكلمات المفتاحية: الافصاح، الافصاح المبكر ، حقوق المساهمين، الحوكمة.

\title{
ROLE OF CORPORATE GOVERNANCE IN PROTECTING INVESTORS' RIGHTS / ANALYTICAL STUDY IN THE IRAQI STOCK EXCHANGE
}

Shada Abdel Hussein Jabr ${ }^{1}$, Fida Adnan Obeid ${ }^{2}$

${ }^{1}$ Assis. Prof. Ph.D. Technical College of Management/baghdad, Middle technical University, Baghdad, Iraq. alshatha2006@yahoo.com

${ }^{2}$ Assis. Prof. Ph.D. Technical College of Management/baghdad, Middle technical University, Baghdad, Iraq. fedaaadnan@ @ahoo.com

\section{ABSTRACT}

The current research focuses on a major problem: the weak role of disclosing corporate information in the application of laws, regulations and instructions related to the application of corporate governance principles weakens the ability to protect the rights of shareholders and investors in companies listed on the Iraqi Stock Exchange and the study aims to study and analyze the role of disclosure and transparency in achieving the necessary protection to ensure the rights of shareholders. The study was applied to a sample of (42) analysis samples representing (84\%) of the total questionnaires distributed to investors and shareholders in all listed companies in the Iraqi Stock Exchange. The results confirm the shareholder's right to obtain guaranteed methods for recording, transferring and transferring ownership of shares, as well as obtaining material and relevant information on a timely basis on a regular basis; participation and voting in the of shareholders; election and removal of board members; The information resulting from the decisions concerning the amendment of the rules of procedure, the memorandum of association or the issuance of the additional shares, or all that leads to the sale of the company. The most important recommendation is the need to oblige companies to prepare quarterly and semi-annual financial reports in addition to the annual reports.

Kay words: Disclosure, Early disclosure, Rights of shareholders, Corporate government. 


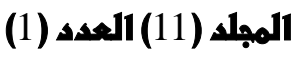

2019 لسنة
المهاة العراقية

لبهوث السوق ومماية المستمهلك

Introduction الفقدمة

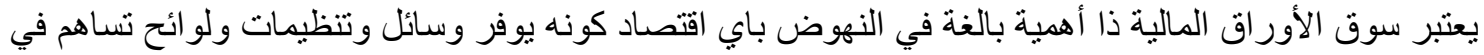

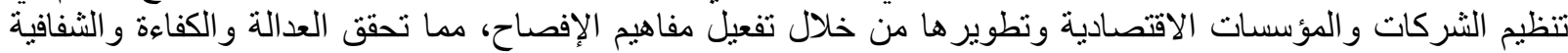

لكافة المعاملات داخل السوق.

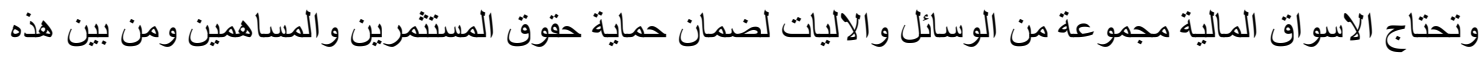

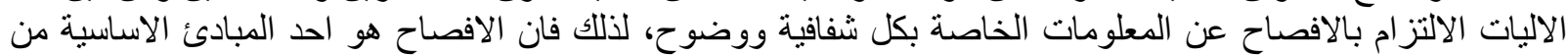

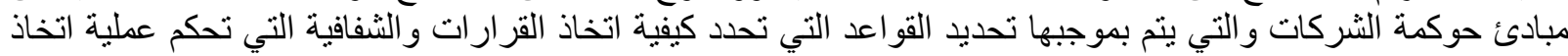

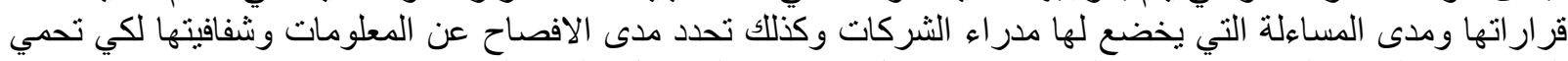

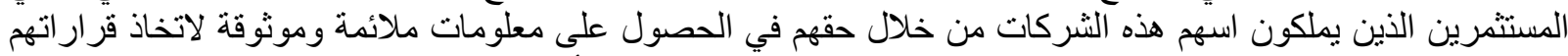

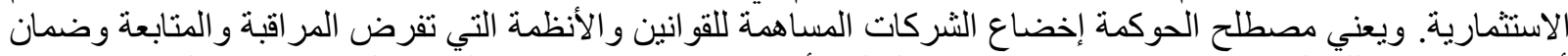

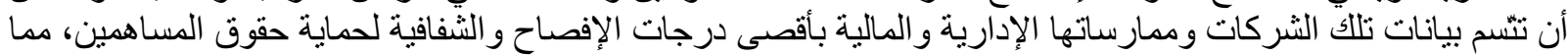

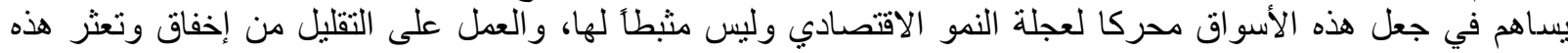

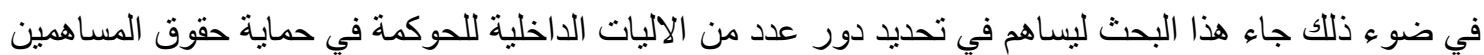

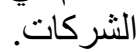

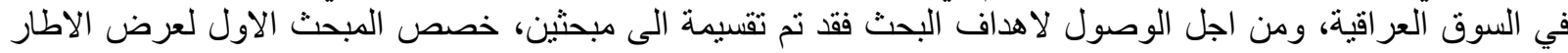

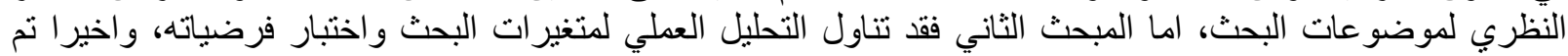

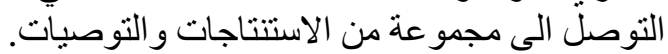

\section{Research M ethodology منهجية البحث}

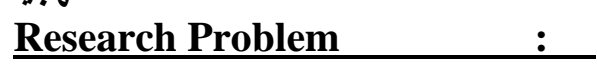

ان تطور السوق المالية يؤدي الى ارتفاع عداع المداع المستثمرين بشكل كبير، وتمثل حوكمة الثركات إطار تنظيمي

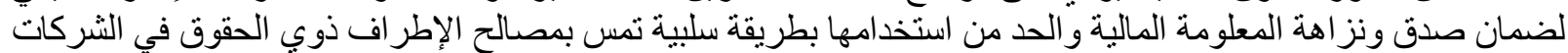

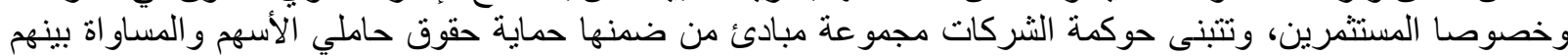

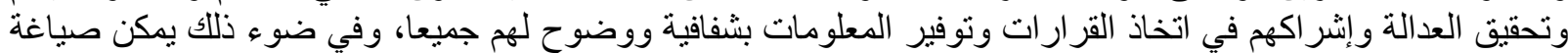

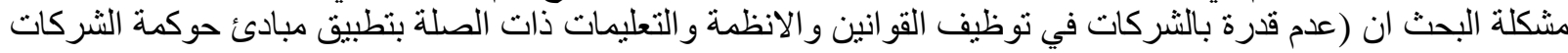

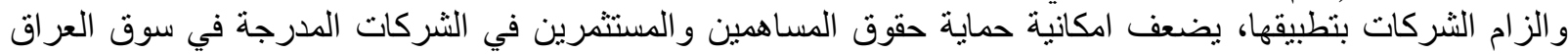

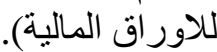

Research Goals ثُانياً: أهداف البحنة)

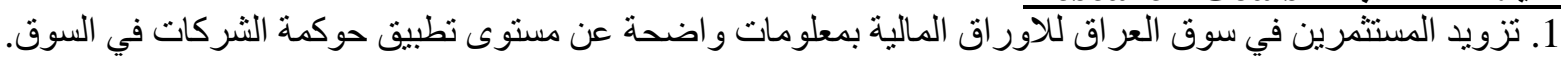

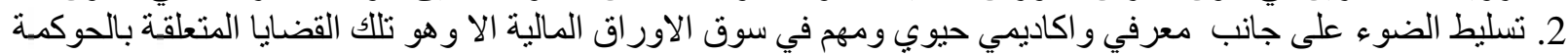
وحماية حقوق المساهمين. 3. دراسة وتحليل دور الحوكمة في تحقيق الحماية اللازمة لضمان حقوق الصمان المساهمين.

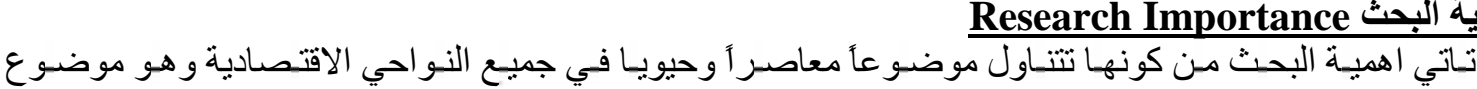

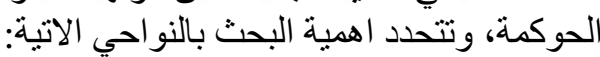

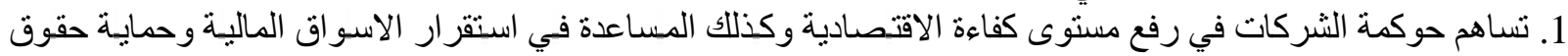
المستثمرين ورفع مستوى الثفافية لهذه الثئر الثركات.

2. تاتي اهمية البحث اليضا من محدودية نقافة حوكمة الشركات لدى بعض الشركات المدرجة في سوق العراق للاور اق المالية.

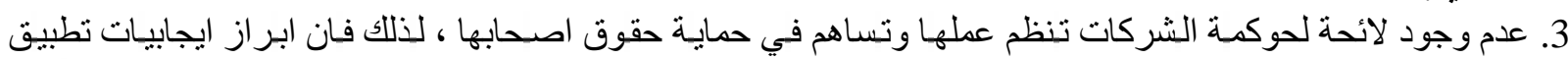

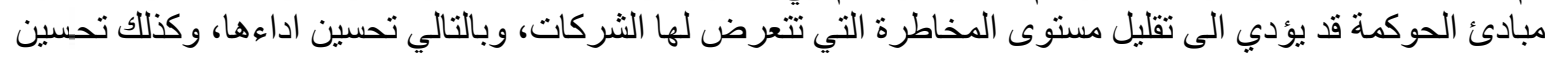

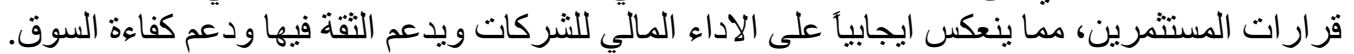

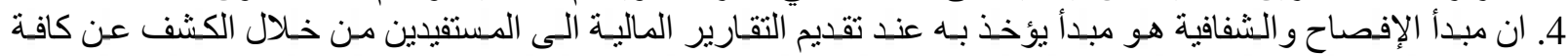

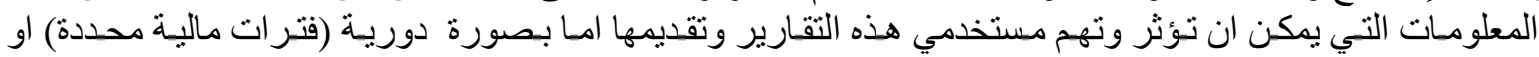

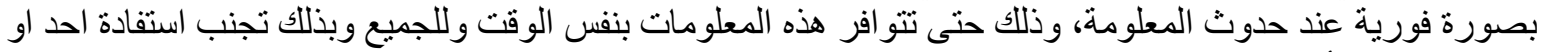
مجمو عة من الأشخاص من المعلومات على حساب المستفيدين الآخرين. 


\section{المجلد (11) العدد (1) (1) (1)}

2019 السنة
المجلة العراقية

لبهوث السوق ومماية المستنهلك

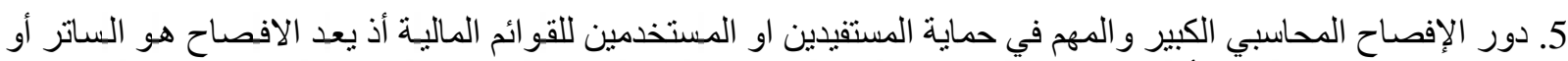

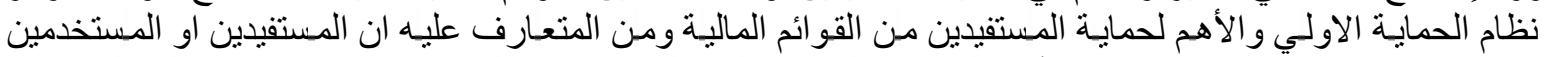

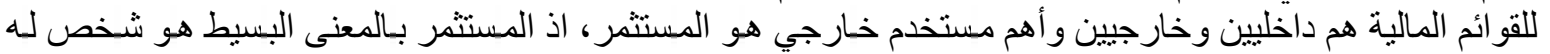

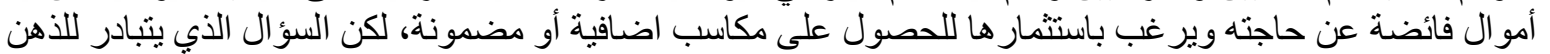

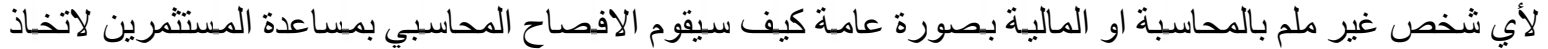

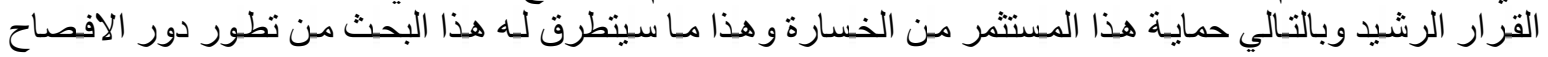

Research Assumes رابعا: فرضية: البحان

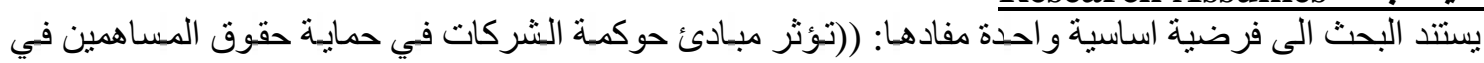

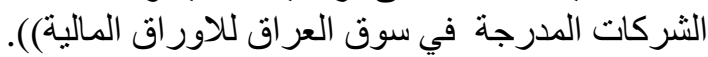

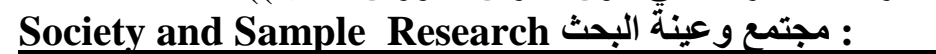

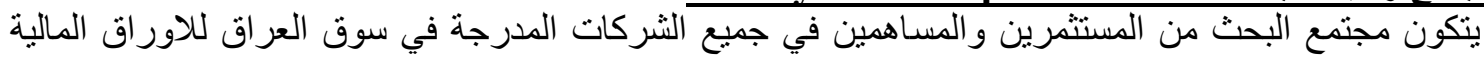

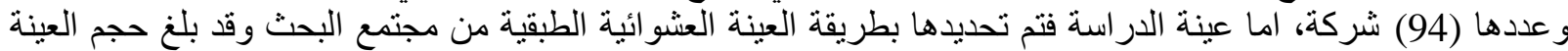

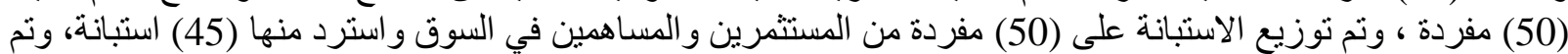

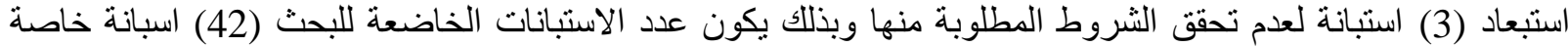
بالتحليل وتمثل (84\%) من مجموع الاستبانات الموز عة، و الجدول التالي يبين التحليل الوصفي لعينة البحث:

\begin{tabular}{|c|c|c|c|}
\hline النسبة ( \%) & التكرار & خصائص العينة & توزيع العينة حسب \\
\hline 52 & 22 & ذكر & \multirow{2}{*}{ الجنس } \\
\hline 48 & 20 & انثى & \\
\hline 26 & 11 & اعدادية & \multirow{5}{*}{ المؤهل العلمي } \\
\hline 21 & 9 & دبلوم & \\
\hline 38 & 16 & بكالوريوس & \\
\hline 12 & 5 & ماجستير & \\
\hline 2 & 1 & اخرى & \\
\hline 43 & 18 & أقل من 5 سنوات & \multirow{3}{*}{ عدد سنوات الخبرة } \\
\hline 43 & 18 & 5 الى 10 سنوات & \\
\hline 14 & 6 & أكثر من 10 سنوات & \\
\hline 40 & 17 & المصارف & \multirow{5}{*}{ القطاع الذي تنتمي الثركة } \\
\hline 26 & 11 & الصناعي & \\
\hline 14 & 6 & الخدمي & \\
\hline 12 & 5 & الاستثمار & \\
\hline 7 & 3 & السياحة و الفنادق & \\
\hline
\end{tabular}

ساسا: ادوات الدرلسة Study T ools

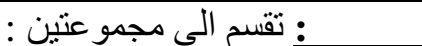

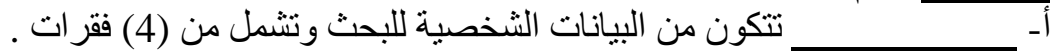

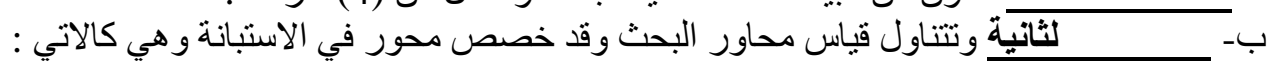
المحور الإط خصص لقياس متغير حوكمة الشركات وفق الأني:

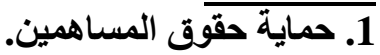
2. 2. المعاملة المتساوية للمساهمين.

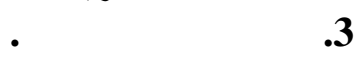
المحور الثافي : خصصاب لمصالح لقياس الافصاح و الشفافية: وقد تم مناقشة كل محور من المحاور من خلال عشرة فقرات في

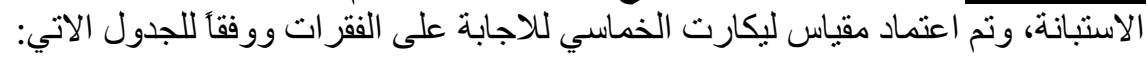

\begin{tabular}{|c|c|c|c|c|c|}
\hline غير مو افق بشدة & غير موافق & محايد & مولفق & موافق بحدود & رجة \\
\hline 1 & 2 & 3 & 4 & 5 & رجه \\
\hline
\end{tabular}




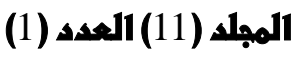

2019 1سنة
المهاة العراقية

لبهوث السوق ومماية المستمهلك

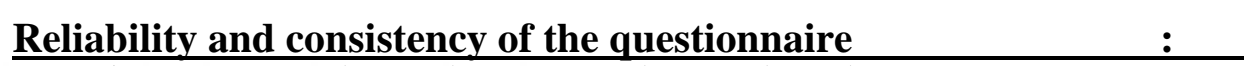

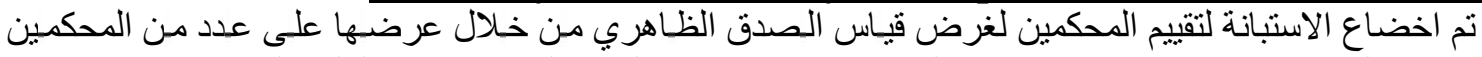

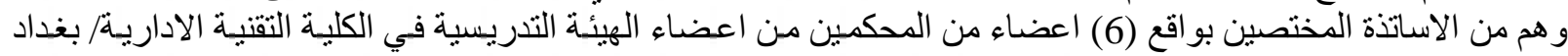

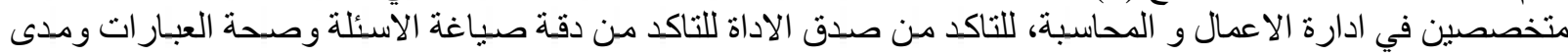

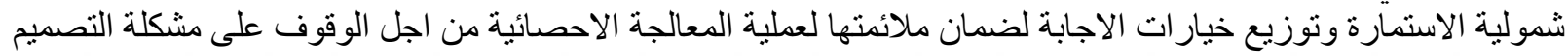

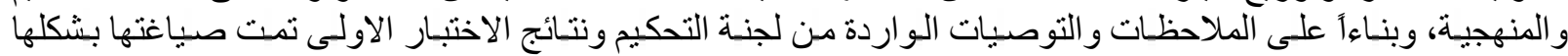

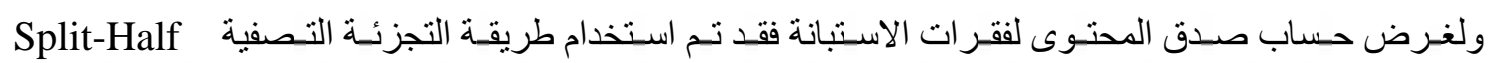
النهائي. Coefficient

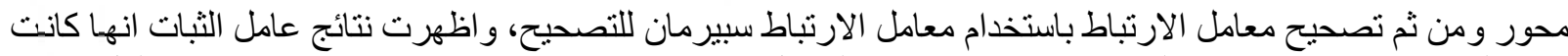

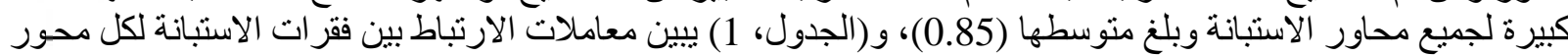

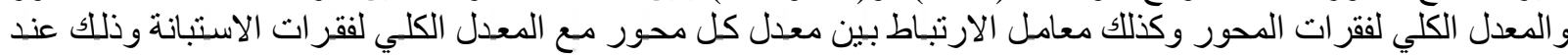

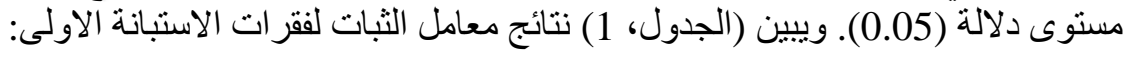

\begin{tabular}{|c|c|c|c|c|}
\hline معبيرمان ارتبلا & معامل ارتبلاً & الفقرات & المحور & ت \\
\hline 0.77 & 0.63 & $X_{10}-X_{1}$ & الاول & 1 \\
\hline 0.86 & 0.76 & $X_{20}-X_{11}$ & الثاني & 2 \\
\hline 0.84 & 0.72 & $X_{30}-X_{21}$ & الثالث & 3 \\
\hline 0.81 & 0.68 & $X_{40}-X_{31}$ & الر ابع & 4 \\
\hline 0.91 & 0.85 & مجموع الفقرات & مجموع المحاور & \\
\hline
\end{tabular}

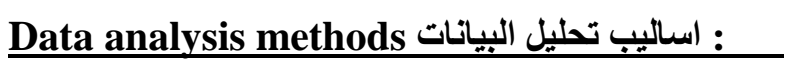

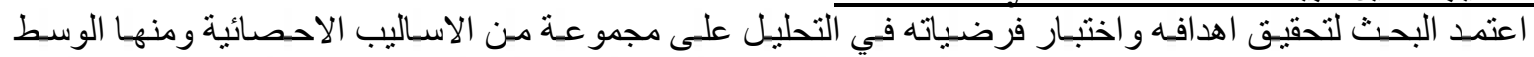

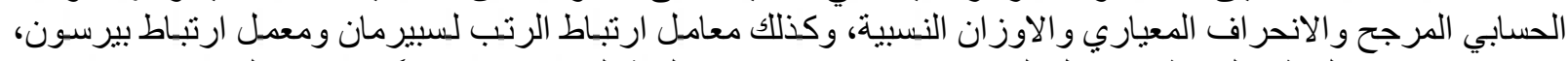

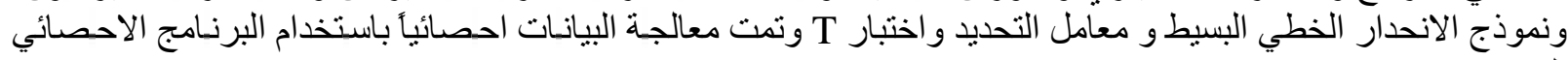

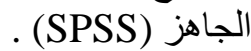

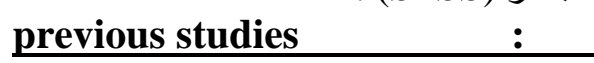

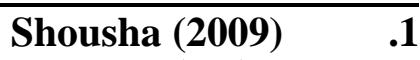

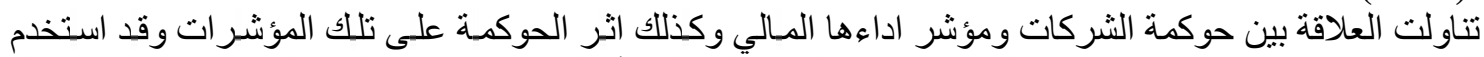

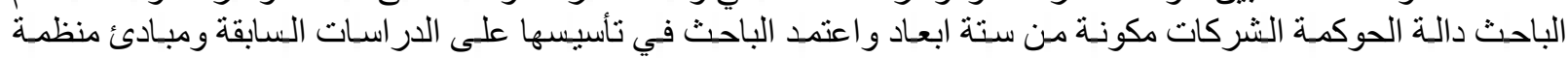

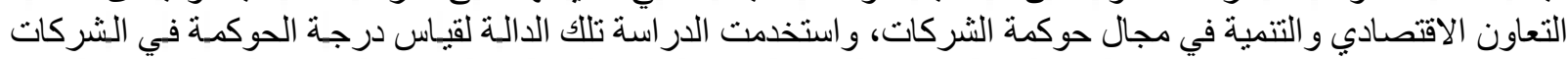

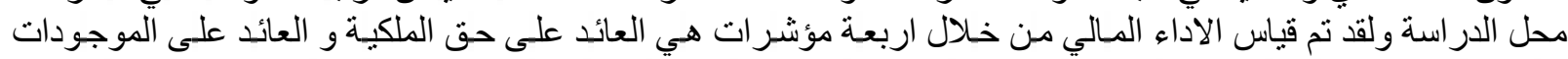

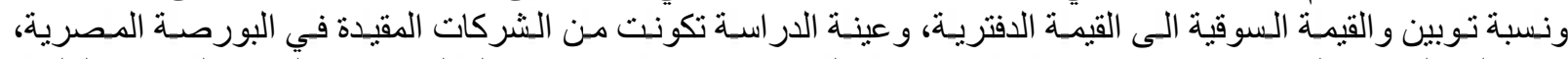

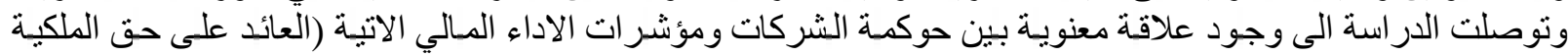

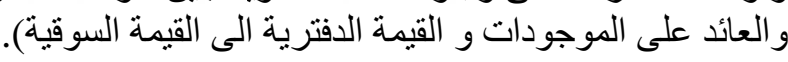

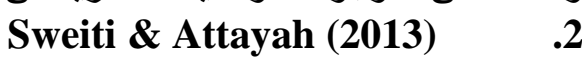

"Critical Factors Influencing Voluntary Disclosure: The Palestine Exchange" "

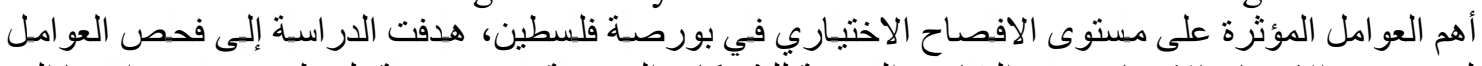

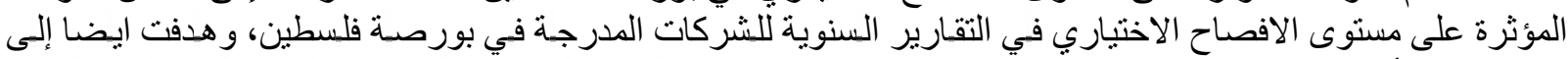

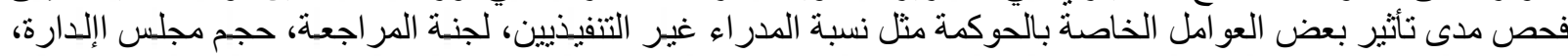

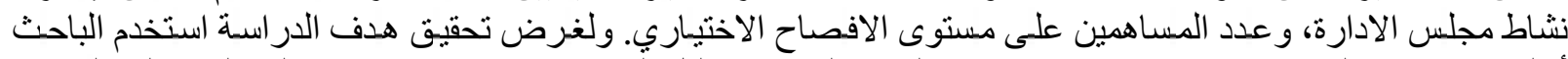

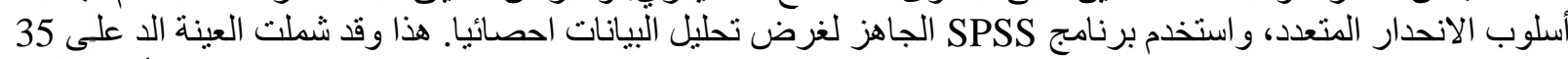

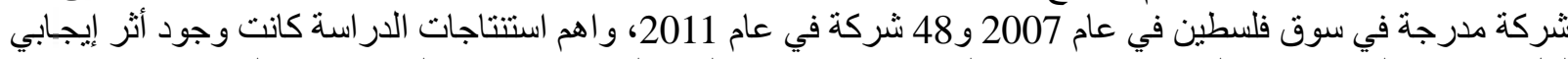

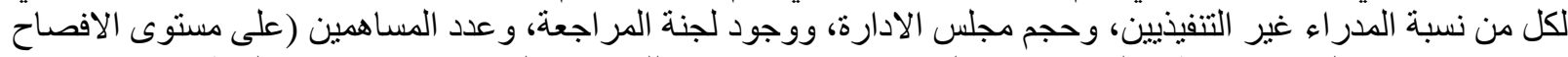
الاختياري)، بينما لم يؤثر نشاط مجلس الادارة على الافصاح الاختياري للشركات المدرجة في بورصة النّة فلسطين. 


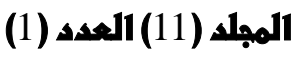

2019 1سنة

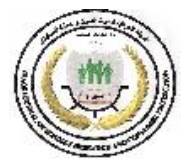

A beywardana \& Panditharathna (2016) 3راسة

The Extent and Determinants of Voluntary Disclosures in Annual Reports: Evidence from Banking and Finance Companies in Sri Lanka

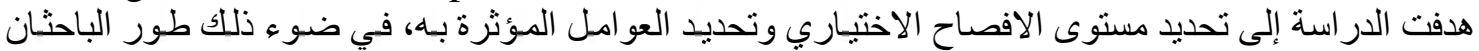

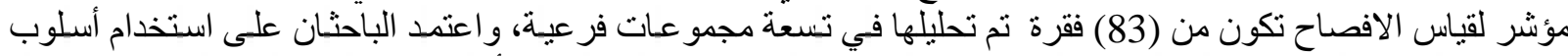

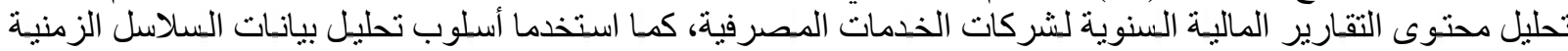

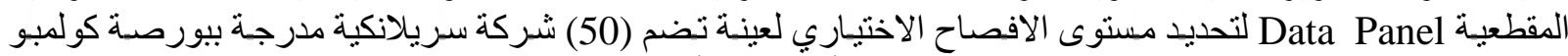

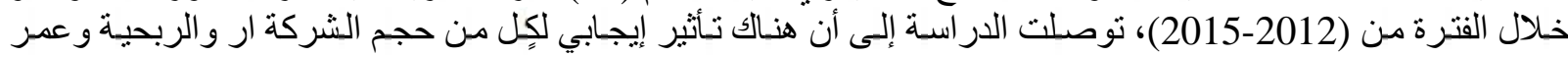
الثركة في مسنوى الافصناح الاختياري ككل.

\section{Theor etical assumption of corporate governance}

\section{اولا : حوكمة الشركات Corporate governance \\ 1. مفهوم وا همية حوكمة الشركات The concept and importance of corporate governance}

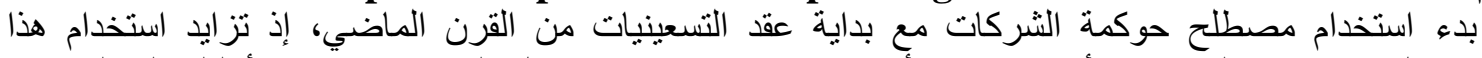

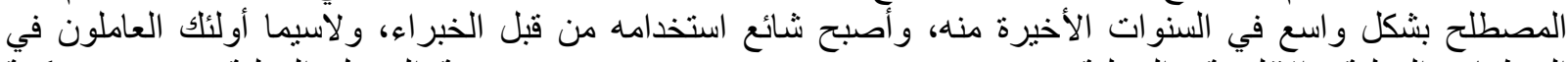

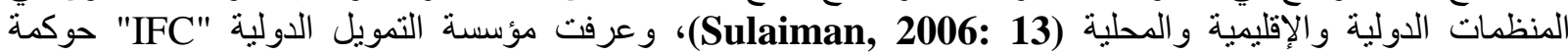

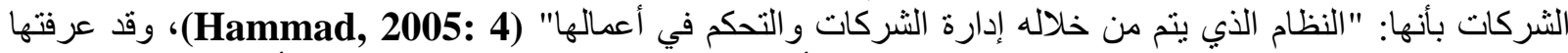

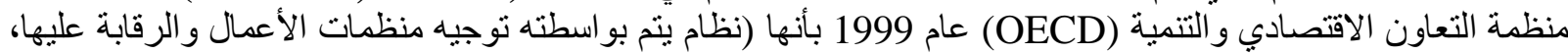

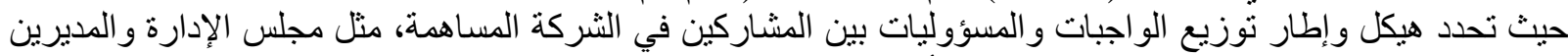

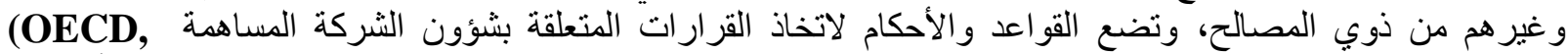

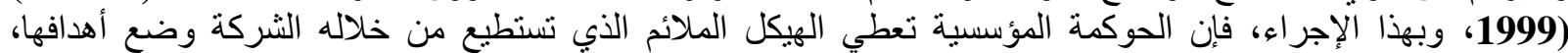

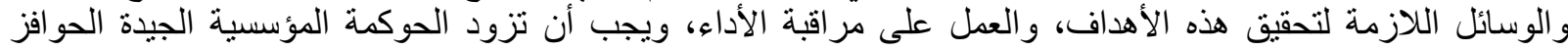

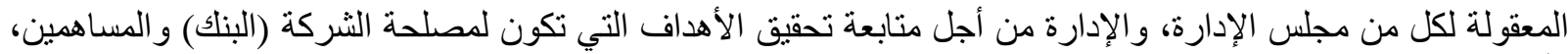

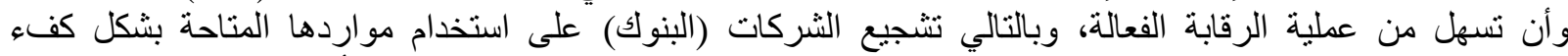

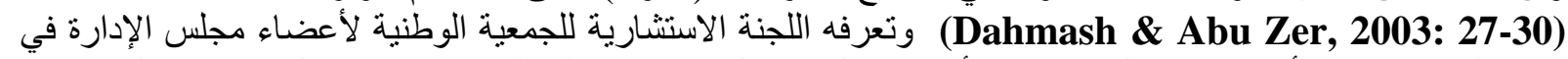

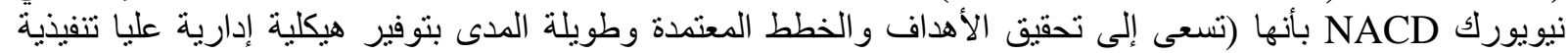

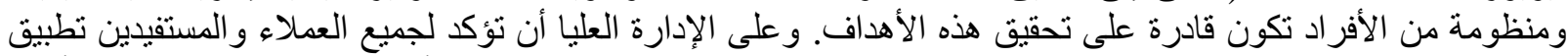

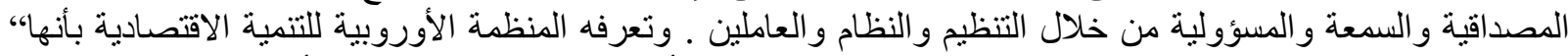

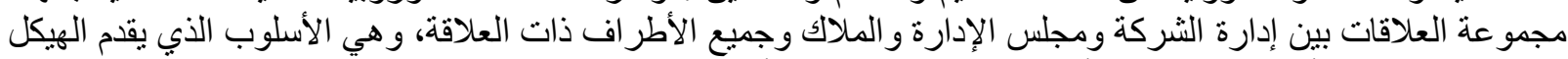

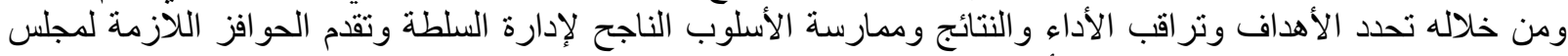

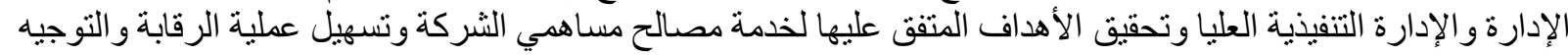

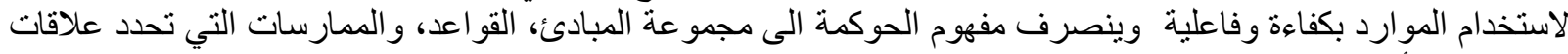

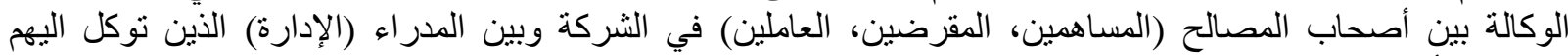

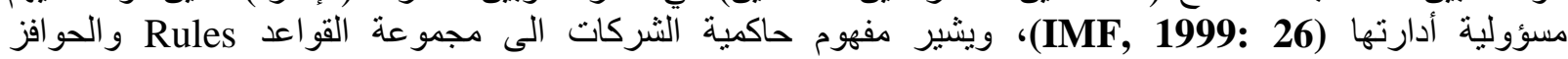

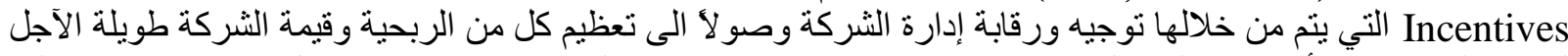

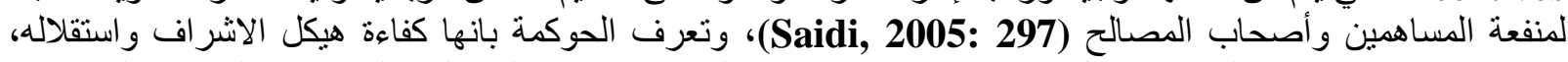

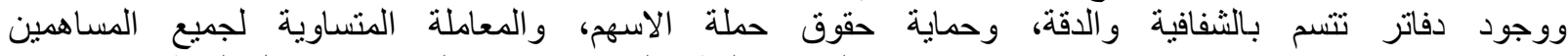

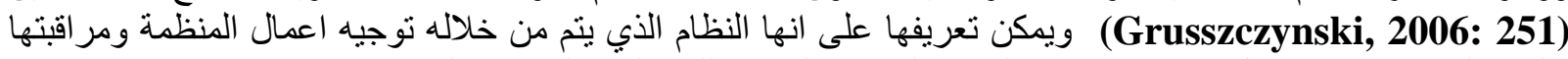

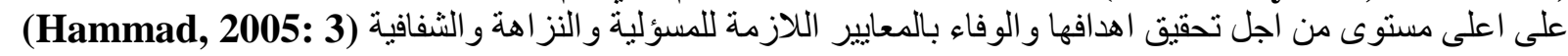

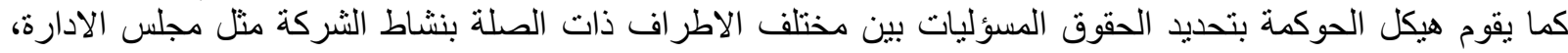

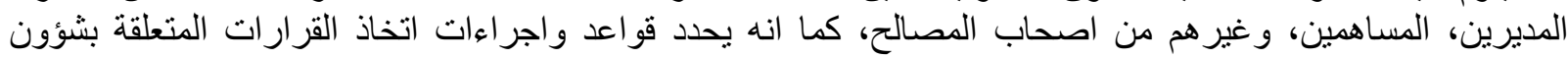

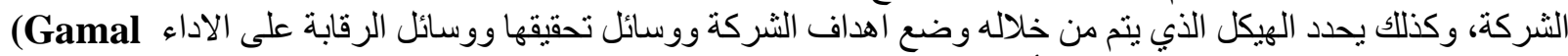

(M و Din, 2006: 19) ـ تحقيق الحياد و الاستقلال لكافة العاملين في الشركات في مختلف المستويات التنظيمية. 


\section{المجلك (11) العدد (1)}

2019 لسنة

\section{المهلة العراقية}

لبهوث السوق ومماية المستنملك

ـ ـقليل الأخطاء إلى أدنى قدر مدكن، والاعتماد على الضوابط الوقائية التي تمنع حدوث الأخطاء، ومن ثم تفادي تكاليف حدوثها.

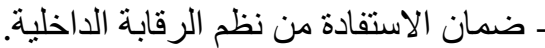

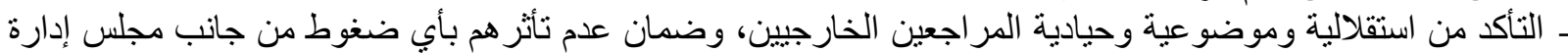

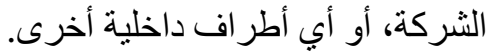

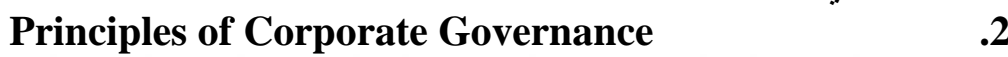

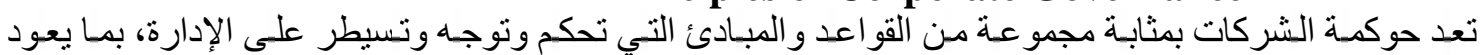

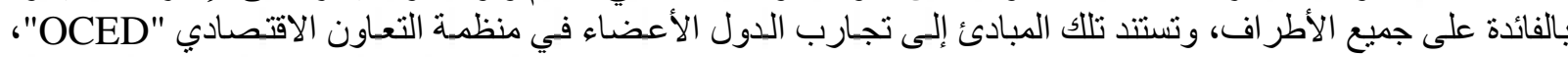

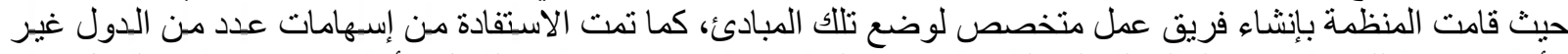

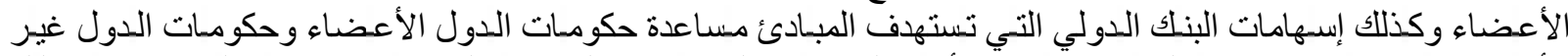

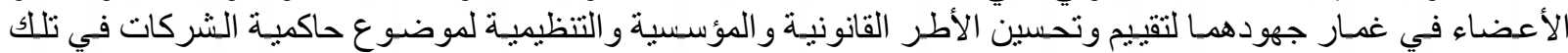

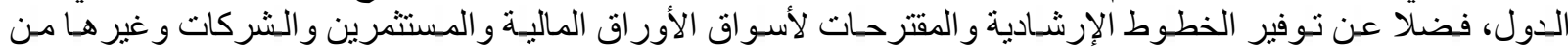

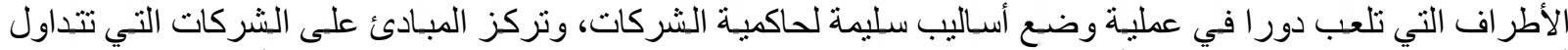

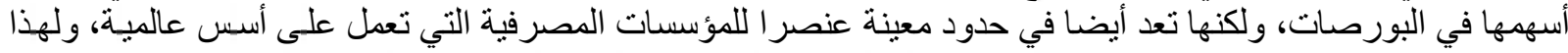

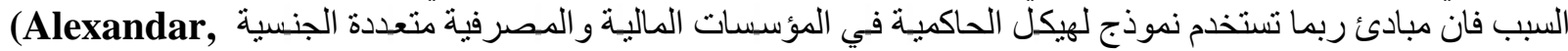

.2004: 9)

لقد كان للمبادئ الخمسة الصادرة عن منظمة (OECD) في سنة 1999 دور ا في تأسيس إطـار قانوني ومؤسساتي

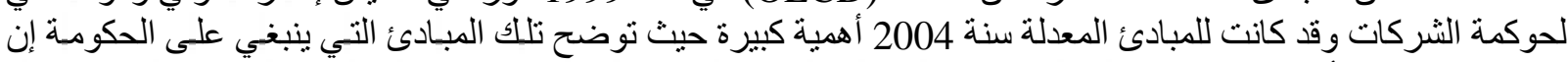

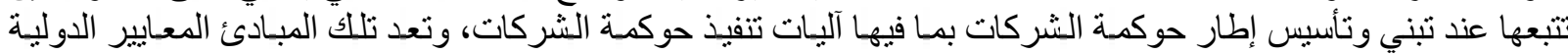

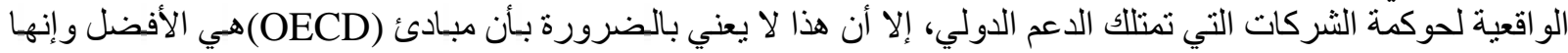

كافية بشكل نهائي (Xiaochuan, 2004: 4).

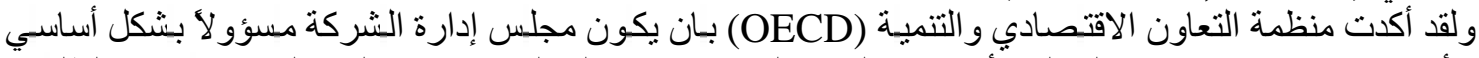

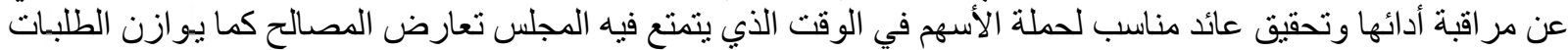

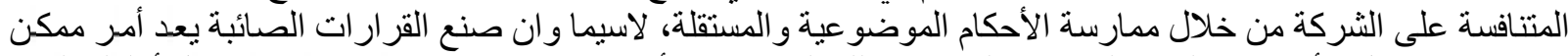

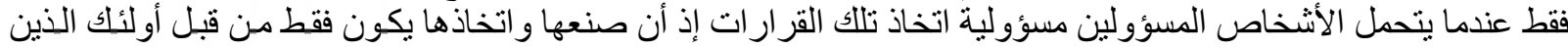

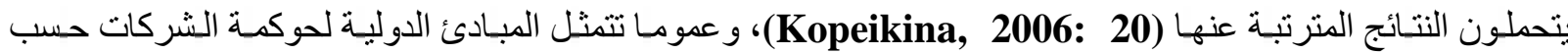

: لعام 2004 النواحي التالية (OCED"

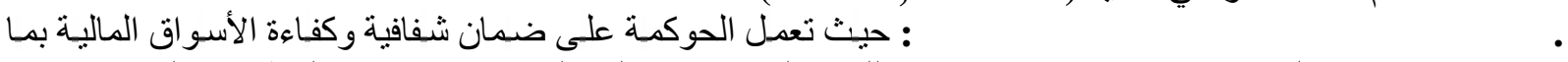

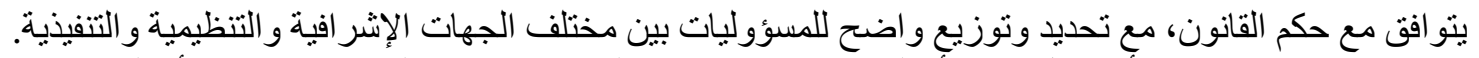

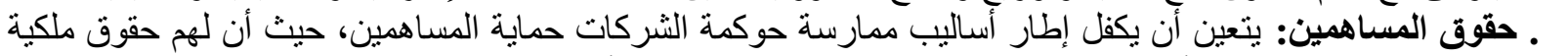

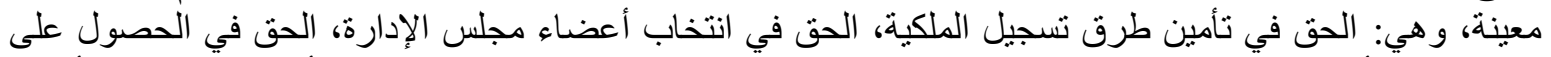

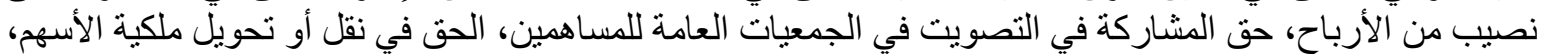

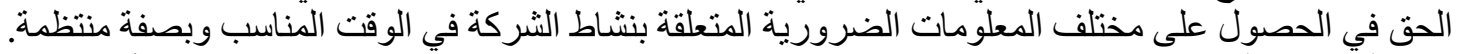

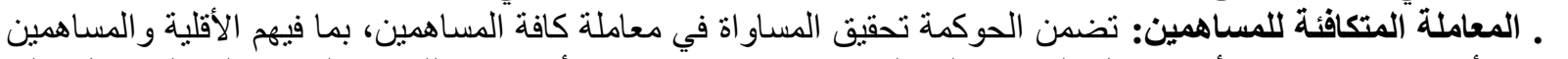

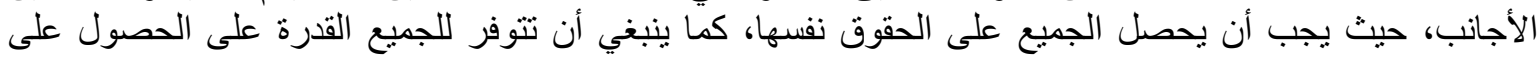

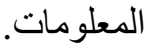

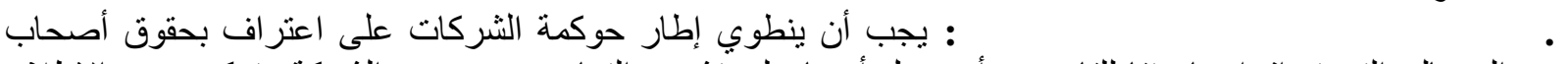

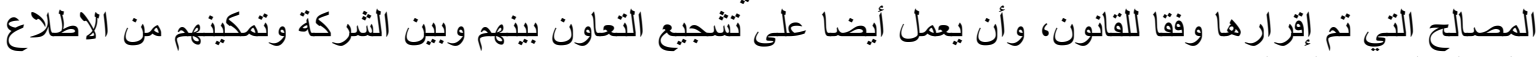

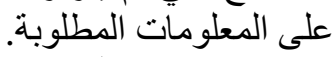

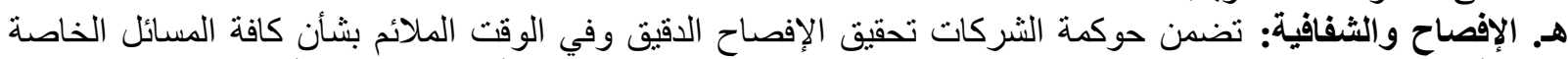

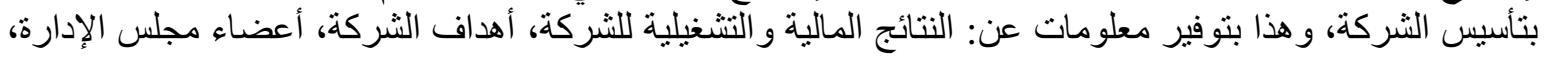

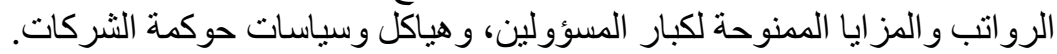

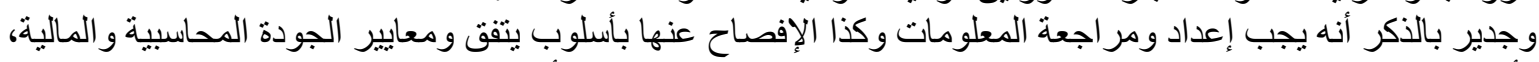
وأيضا بمتطلبات عمليات المراجعة، بهدف إتاحة التدقيق الموضوعي للأسلوب المستخدم في إعداد القوائم المالية وصياغة التقارير المالية.

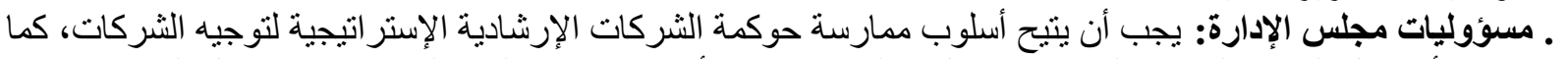

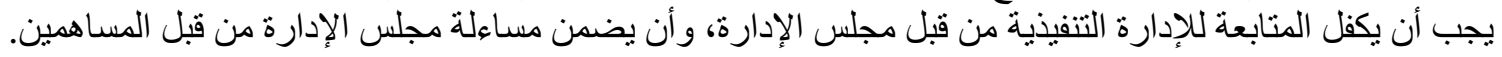




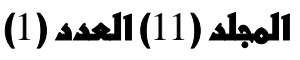

2019 لسنة
المجاة العراقية

لبهوث السوق ومماية المستمهلك

ثisclosure ثانيا: الافصاح

The C oncept of Disclosure sفهوم الإفصاح

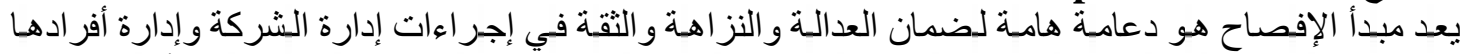

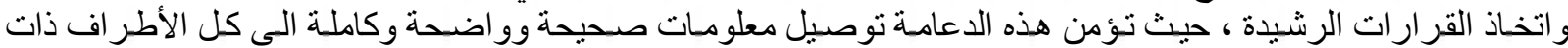

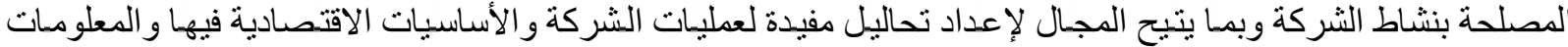

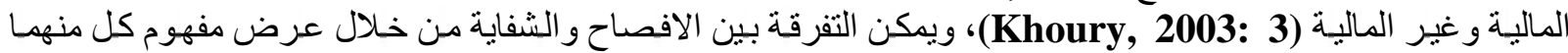

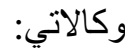
ـ الإفصاح هو عرض اللمعلومات الضرورية عن الوحدة الاقتصادية لإغراض التشغيل الأمثل لأسواق رأس المال الفعال

\section{(Hendriksen \& Breda, 1995: 54)}

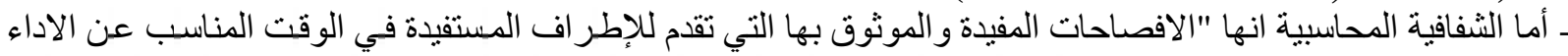

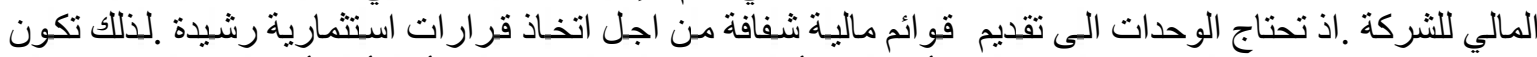

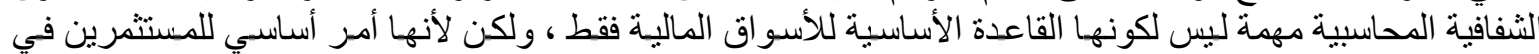

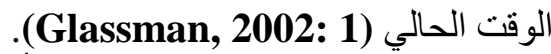

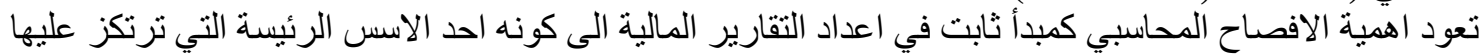

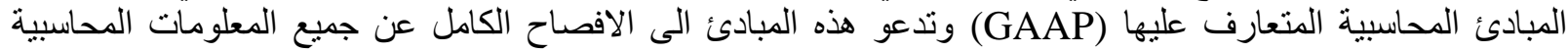

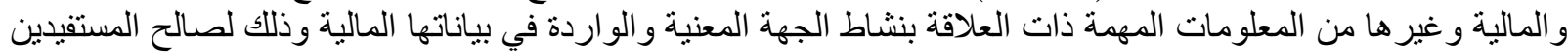

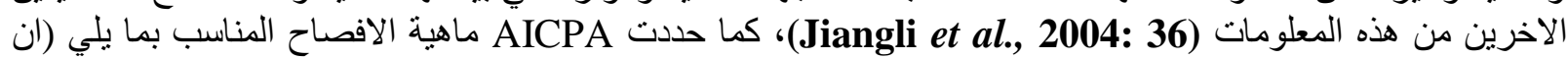

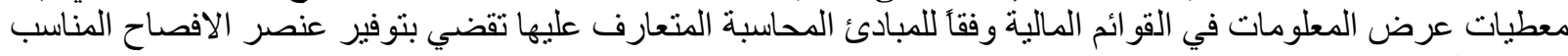

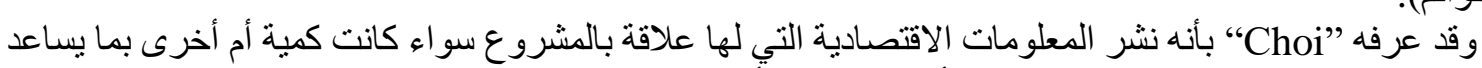
في هذه القو ائم).

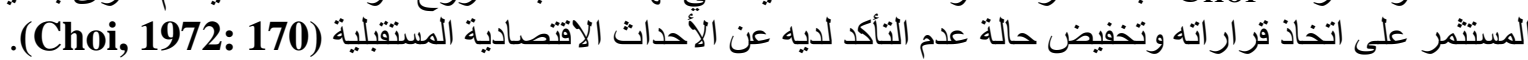

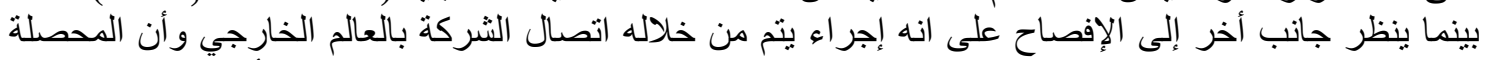

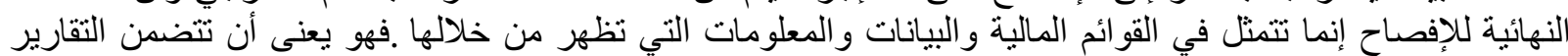

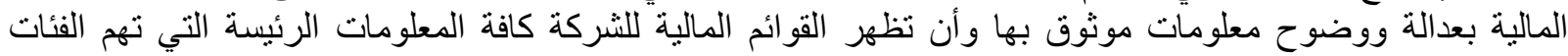

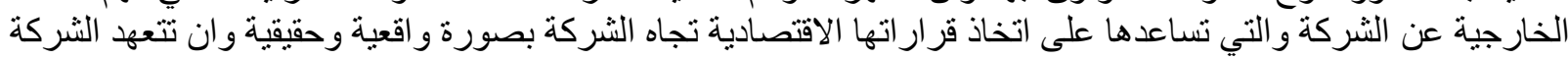

بتقديم تلاك المعلومات بصفة دورية (G yan, 1974: 733)

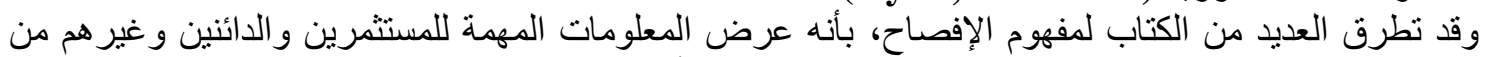

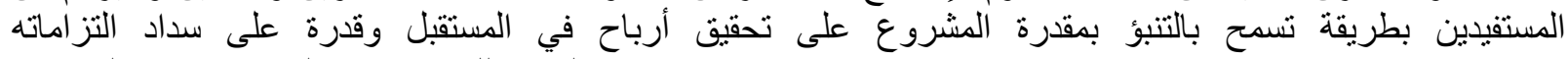

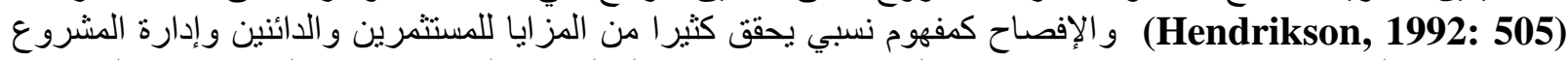

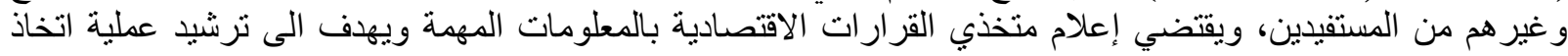

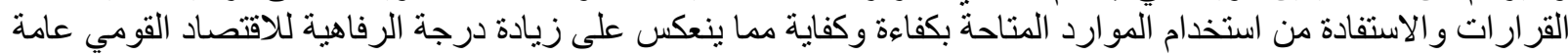

.(Turki, 1989: 27)

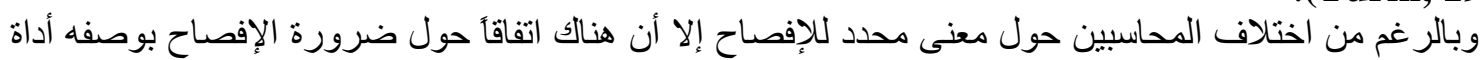

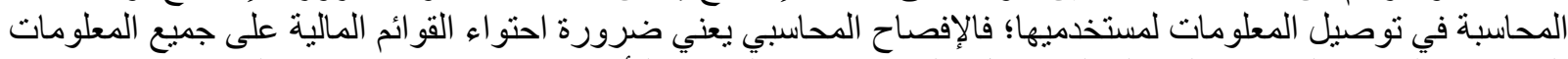

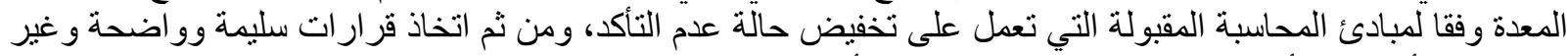

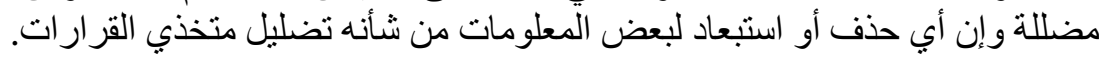

Importance of disclosure 2

يمكن حصر أهمية الافصاح بالنسبة للمستثمرين في النقاط التالية (Sahnoun, 2008: 121-122):

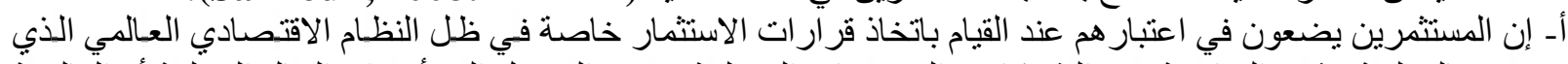

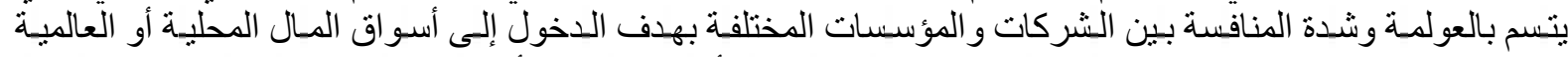

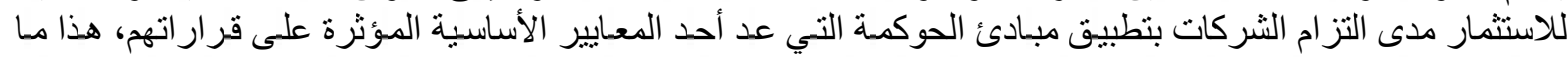

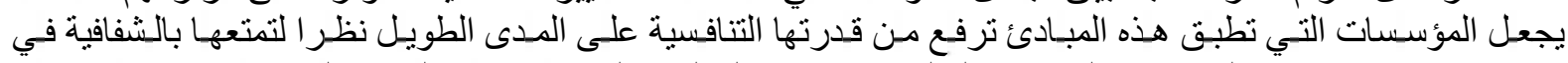

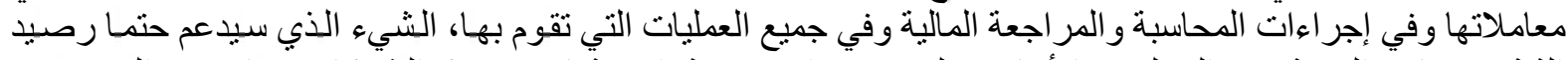

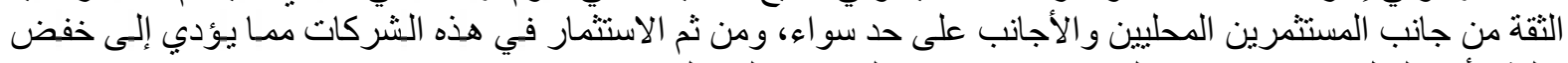

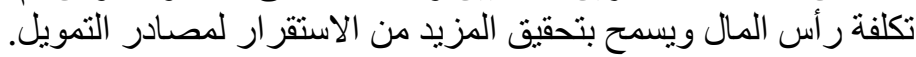

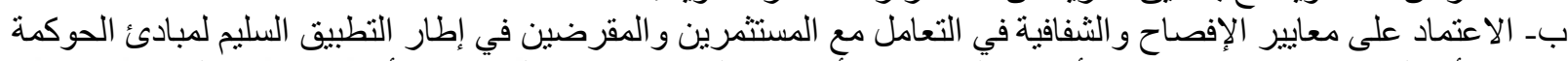

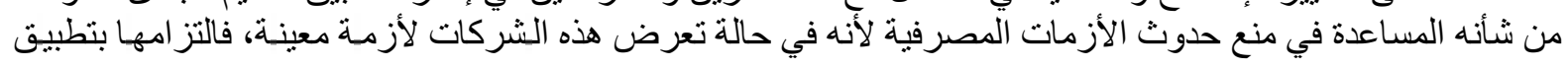




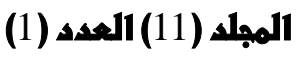

2019 لسنة
المهاة العراقية

لبهوث السوق ومماية المستمهلك

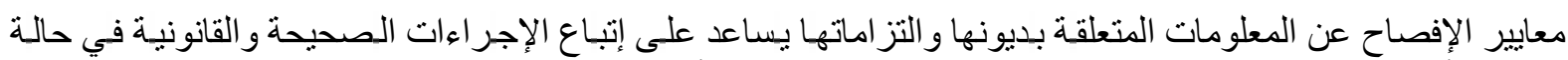

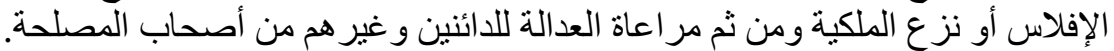

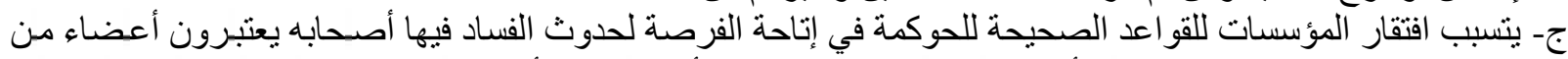

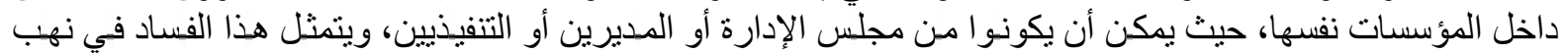

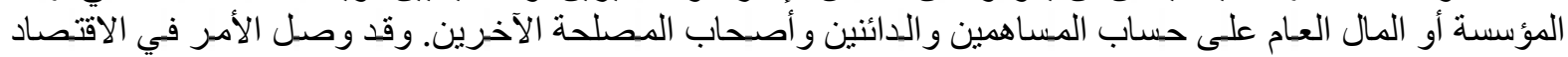

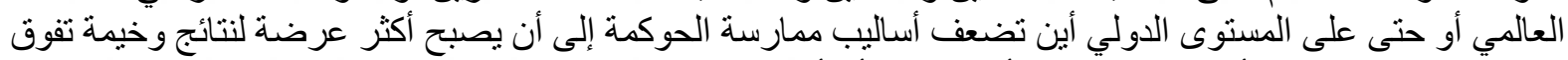

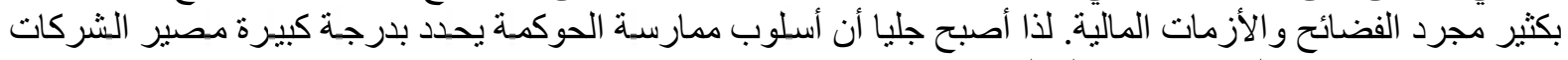

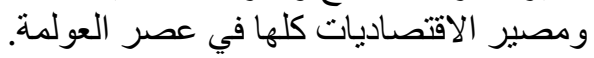

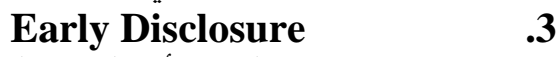
يرى بعض الكتاب أن القوائم المالية المتعلقة بنهاية السنة المالية قليلة القيمة إذا لم يتم إصدار قوائم المائم مالية دورية

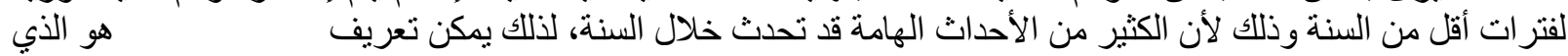

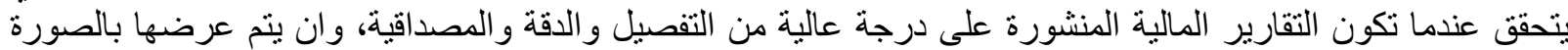

والوقت الذي يناسب احتياجات ورغبات كل مستخدم ذي مصلحة (M akhlouf, 2009: 5).

4. مستويات وأنواع الإفصاح المحاسبي Accounting Disclosure L evels and Types

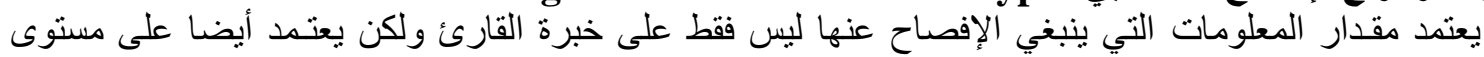

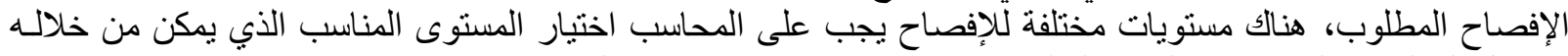

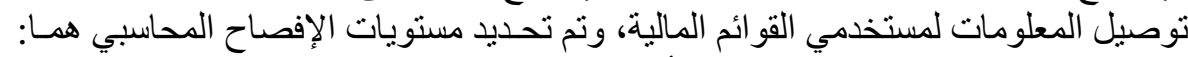

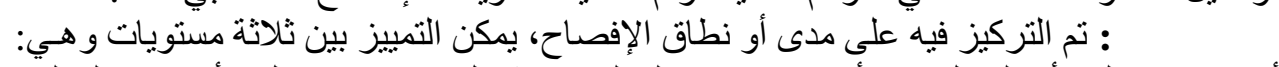

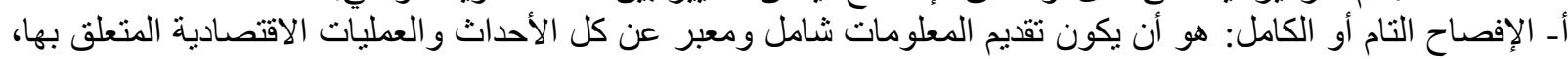

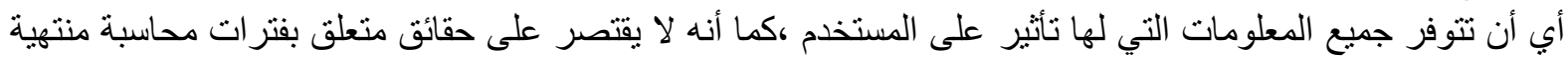

بل يشمل الوقائع اللاحقة (Ziyud, 2007: 18)

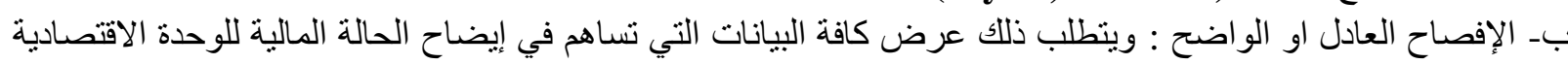

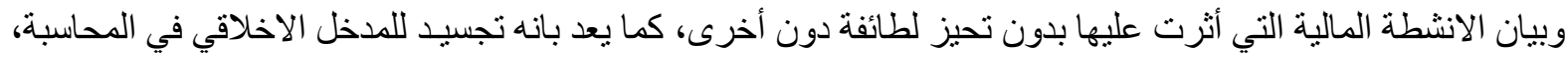

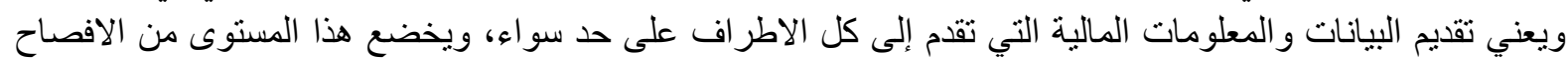
إلى اعتبار ات سلوكية تتعلق بمعدي البيانات المحاسبية (Zouina, 2014: 141).

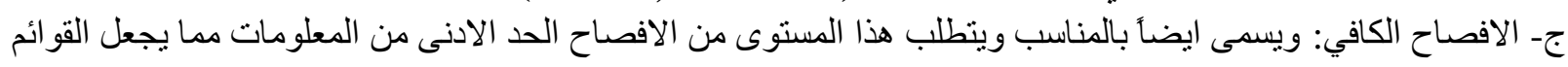

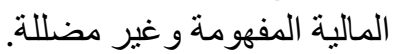

(Frederick et al., 2004: المدظل الثاف: في هذا المدخل يتم النركيز على نو عية الإفصاح، حيث يقسم الإفصاح إلى

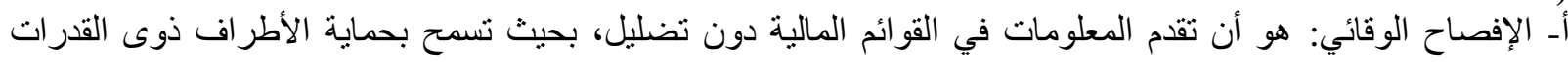

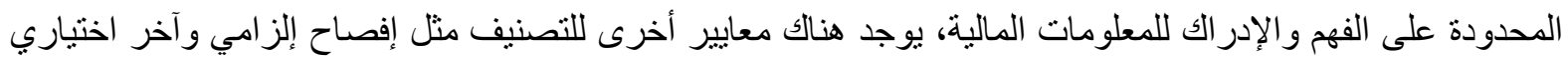

(Zouina, 2014: 180)

بـ الافصاح الاختياري والافصاح الاجباري: ويرجي الإنع تصنيف الافصاح الى اختياري او اجباري الى البيئة والتشريعات و والقو انين النافذة في تللك البيئة. ج- الإفصاح التتقفي (الإعلامي): وهو اتجاهي التهاه معاصر يعتمد على أن مستخدم البيانات المالية لديه القدرة على التحليل و عقد

المقارنات واجر اء التنبؤات بطريقة مهنية (Alhayali, 2007: 372)

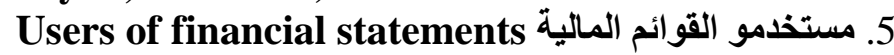

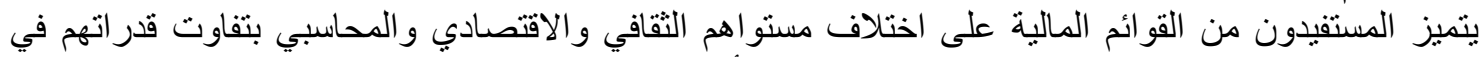

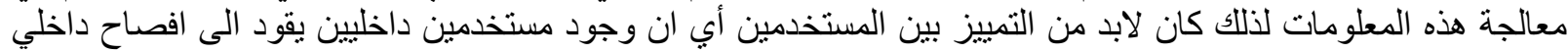

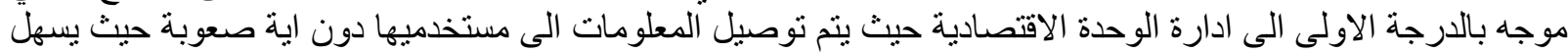

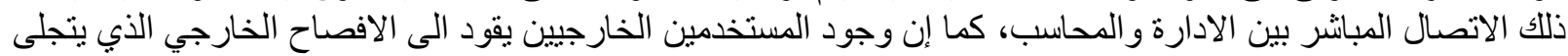

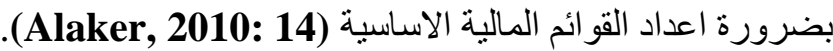

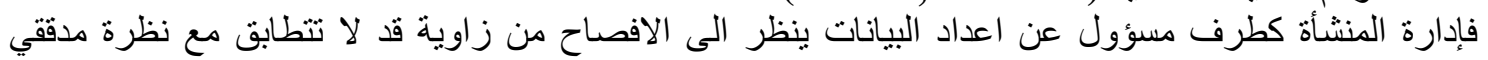

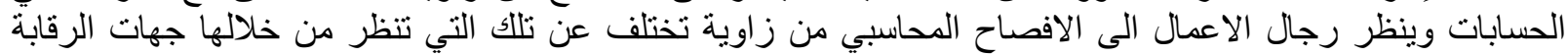

و الاشر اف، وبالنهاية ينظر كل طرف يطالب بالافصاح بحيث يحقق هدفه ومصلحته (Alzubaidi 2000: 96). 
المهله (11) 11 العده (1)

2019 لسنة
المهاة العراقية

لبهوث السوق ومماية المستنهلك

The importance of applying the systems of protection of shareholders' rights

ثالثا: اهمية تطبيق نظم حماية حقوق المساهمين

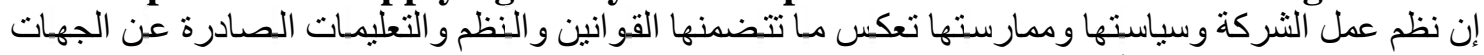

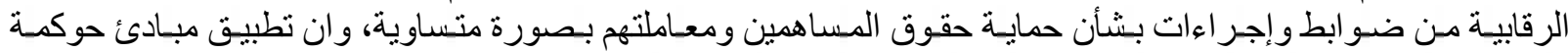

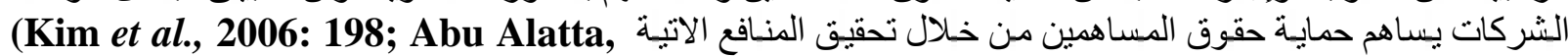

:2003: 22; Shleifer \& Vishny, 1997: 737-744)

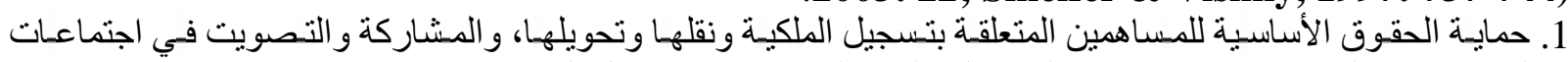

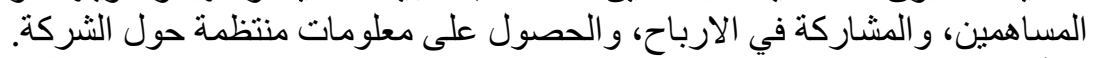

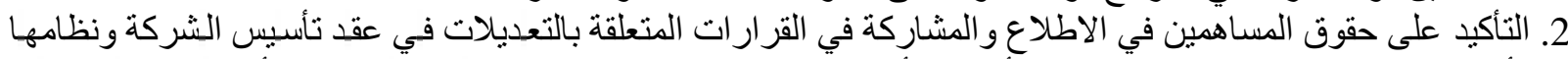

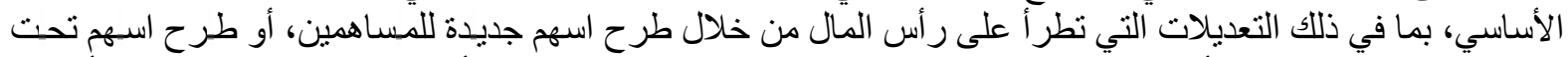

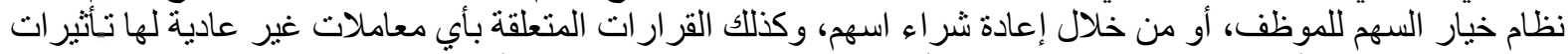

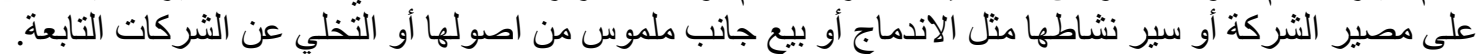

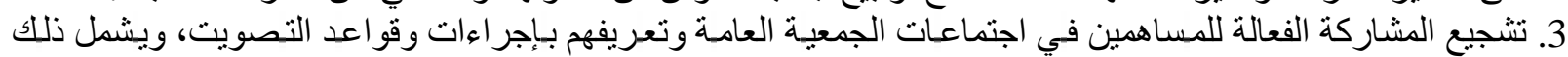

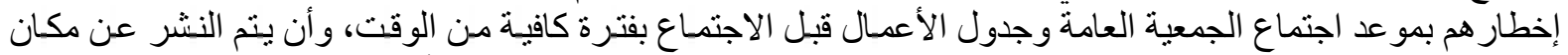

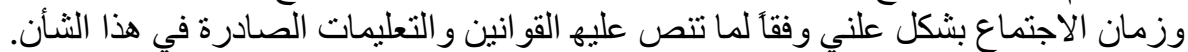

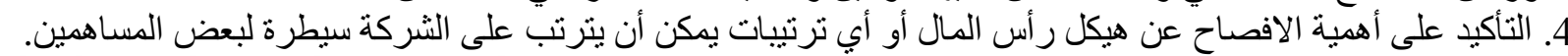

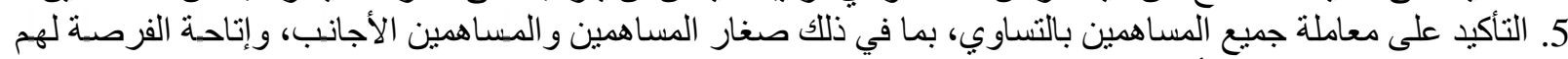

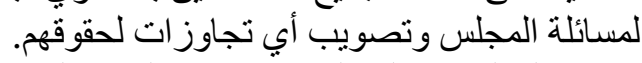

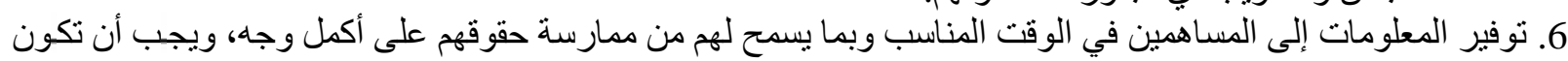

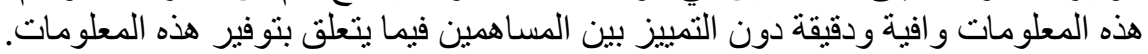

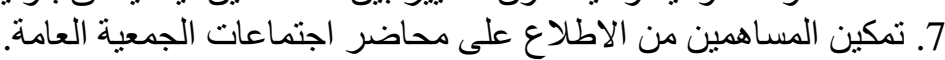

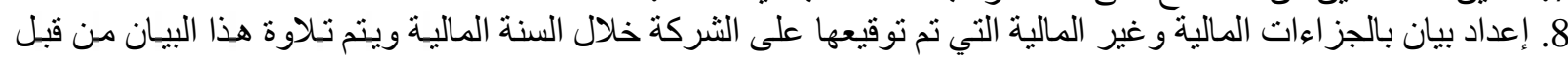
رئيس مجلس إدارة الثركة في اجتماع الجمعية العامة السنوي.

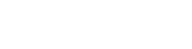

تصليل فقرات الاسنبانة واختبار الفرضيات

\section{Analysis of vertebrae and hypothesis testing}

\section{Analysis of variances for sample responses (research sample description)}

\section{اولا: تحليل الفروق لاجابات عينة البحث (وصف عينة البحث)}

\section{يلاحظ من (الجدول، 2) ليتوسط إجابات عينة البحث على اسئلة محاور الاستنبيان الاتي:}

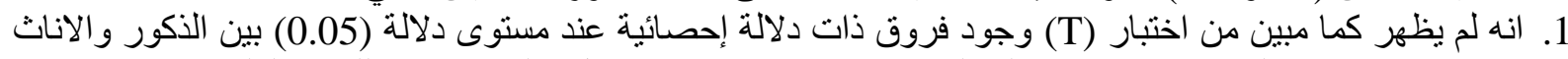

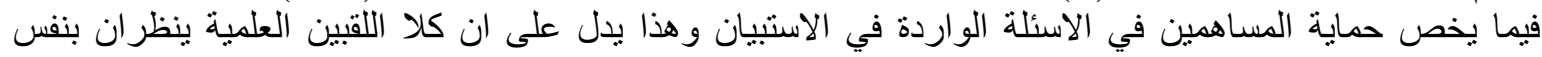

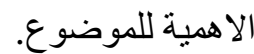
2. فيما يخص الفروق ذات الدالة الإحصائية لمتغير القطاع الذي ينتمي اليه الدستثر فيما يخص اقتتاعهم بدور الافصاح

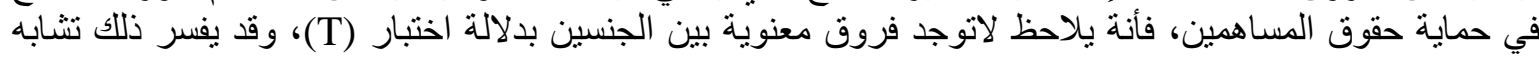

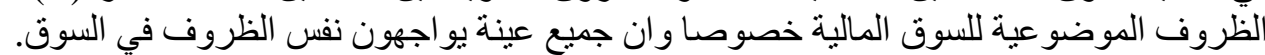
3. لاتوجد فروق معنوية ذات دلالة إحصائية بمستوى (0.05) تعزى لمتغير اللقب العلمي.

جدول (2) : الإحصاءات الوصفية لعينة البحث.

\begin{tabular}{|c|c|c|c|c|c|c|c|}
\hline الفروق في الانحراف & اختبار T & FتبارF & المعياري & المتوسط & التكرار & البيان & توزيع العينة حسب \\
\hline \multirow{2}{*}{8.157} & \multirow{2}{*}{2.914} & \multirow{2}{*}{1.915} & 1.623 & 3.658 & 22 & ذكر & \multirow{2}{*}{ الجنس } \\
\hline & & & 1.051 & 4.078 & 20 & انثى & \\
\hline \multirow{5}{*}{4.445} & \multirow{5}{*}{8.03} & \multirow{5}{*}{4.55} & 0.88 & 3.61 & 11 & اعدادية & \multirow{5}{*}{ المؤهل العلمي } \\
\hline & & & 0.94 & 3.17 & 9 & دبلوم & \\
\hline & & & 0.71 & 4.18 & 16 & بكالوريوس & \\
\hline & & & 1.03 & 3.99 & 5 & ماجستير & \\
\hline & & & 0.94 & 4.24 & 1 & اخرى & \\
\hline
\end{tabular}


المهلد (11) العدد (1) (11)

2019 لسنة
المهاة العراقية

البهوث السوق ومماية المستمهلك

\begin{tabular}{|c|c|c|c|c|c|c|c|}
\hline \multirow{3}{*}{4.32} & \multirow{3}{*}{3.11} & \multirow{3}{*}{6.27} & 0.706 & 4.147 & 18 & أقل من 5 سنوات & \multirow{3}{*}{ عدد سنوات الخبرة } \\
\hline & & & 1.017 & 3.956 & 18 & 5 الى 10 سنوات & \\
\hline & & & 0.929 & 4.208 & 6 & أكثر من 10 سنو ات & \\
\hline \multirow{5}{*}{3.98} & \multirow{5}{*}{5.77} & \multirow{5}{*}{5.42} & 0.88 & 3.62 & 17 & المصارف & \multirow{5}{*}{ اليه الثطركة ألي تنتثمي } \\
\hline & & & 0.94 & 3.17 & 11 & الصناعي & \\
\hline & & & 0.71 & 4.19 & 6 & الخدمي & \\
\hline & & & 1.03 & 4.00 & 5 & الاستثمار & \\
\hline & & & 0.94 & 4.25 & 3 & الساحة و الفنادق & \\
\hline
\end{tabular}

\section{Analysis of the paragraphs of the first axis: corporate governance \\ ثانيا: تحليل فقرات المحور الاول: حوكمة الشركات 1. تحليل حماية حقوق المساهمين Equity Protection A nalysis}

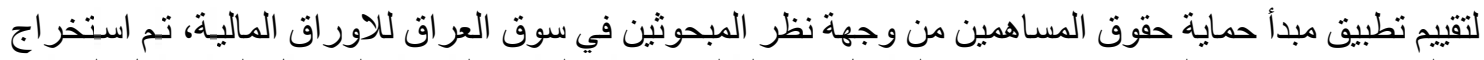

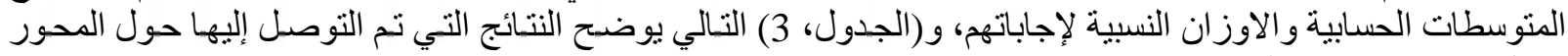

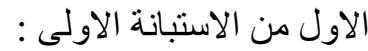
جدول (3): تحليل فقرات المحور الاول/ حماية حقوق المساهمين

\begin{tabular}{|c|c|c|c|c|c|c|c|c|}
\hline \multirow{2}{*}{ 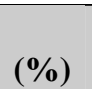 } & \multirow{2}{*}{ الوساب } & \multicolumn{5}{|c|}{ المقياس الخماسي } & \multirow{2}{*}{ 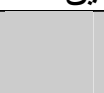 } & \multirow[t]{2}{*}{ مستوى الإجابة } \\
\hline & & 5 & 4 & 3 & 2 & 1 & & \\
\hline 95.2 & 4.40 & - & 1 & 1 & 20 & 20 & 1 & ملكية الاسهر الحقوق الاساسية للمساهمين طر ائق مضمونة لتسجيل وتحويل و نقل \\
\hline 97.7 & 4.52 & - & - & 1 & 18 & 23 & 2 & 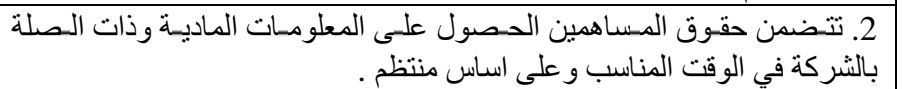 \\
\hline 95.2 & 4.36 & - & 1 & 1 & 22 & 18 & 3 & 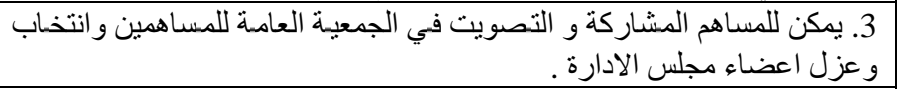 \\
\hline 92.9 & 4.52 & - & 1 & 2 & 13 & 26 & 4 & 4. للمساهم نصبب من ارباح الثركة . \\
\hline 90.5 & 4.36 & - & 1 & 3 & 18 & 20 & 5 & 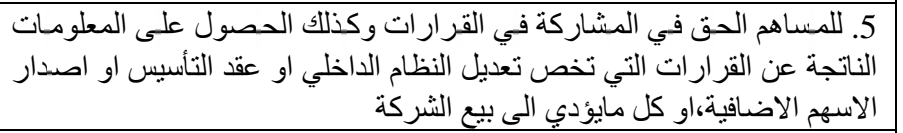 \\
\hline 95.2 & 4.64 & - & - & 2 & 11 & 29 & 6 & 6 6. للمساريخ ومكان وجدول الحصول على المعلومات الكافية في الوقت المنسب فيما يتعلق \\
\hline 83.3 & 4.10 & - & 3 & 4 & 21 & 14 & 7 & للاستيلاء على الثشركة في مسألة مجلـس الادارة حـول اسـتخدام الوسـائل المـضـادة \\
\hline 90.5 & 4.24 & - & 1 & 3 & 23 & 15 & 8 & 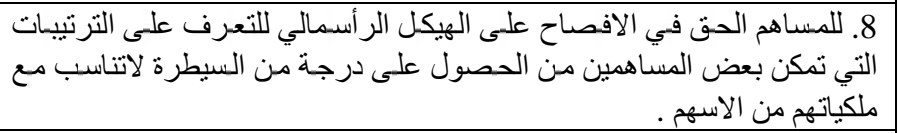 \\
\hline 90.5 & 4.12 & - & - & 4 & 29 & 9 & 9 & 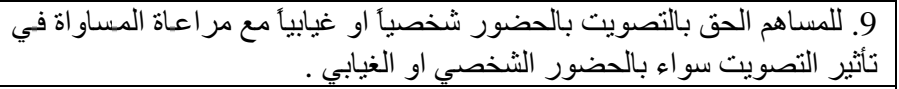 \\
\hline 88.1 & 4.38 & - & - & 5 & 16 & 21 & 10 & 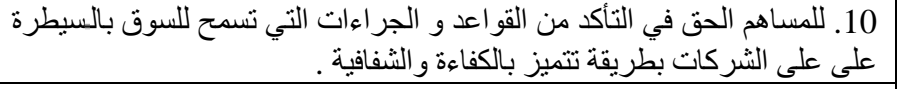 \\
\hline 91.91 & 4.364 & & 1.33 & 2.6 & 19.1 & 19.5 & & المتوسط \\
\hline
\end{tabular}

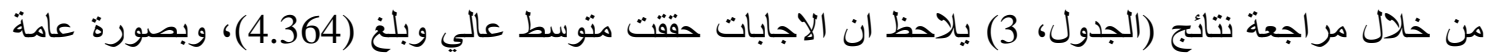

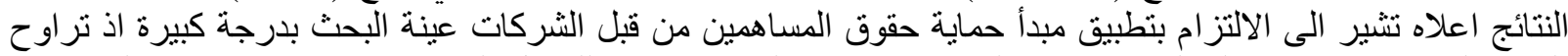

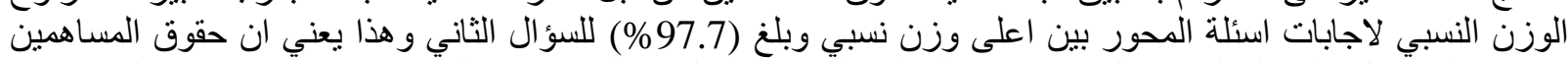

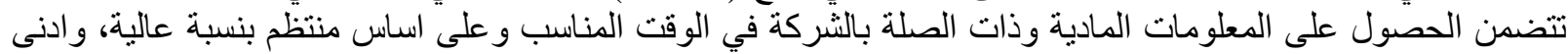

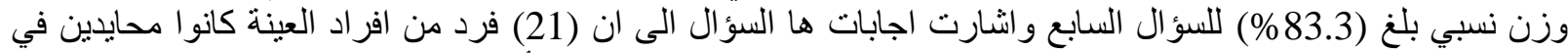

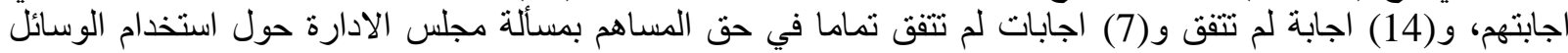
المضادة للاستيلاء على الثركة. 
(1)

لسنة 2019
المجلة العراقية

لبهوث السوق ومماية المستنهلك

2. تحليل فقرات المعاملة المتساوية للمساهمين Analysis of equal treatment clauses for shareholders يعرض( الجدول، 4) التالي نتائج تحليل المحور الثاني (المعاملة المتساوية للمساهمين): جدطل (4): تحليل فقر ات الثاني / المعاملة المتساوية للمساهمين المبانين

\begin{tabular}{|c|c|c|c|c|c|c|c|c|}
\hline \multirow{2}{*}{ النسبة (\%) } & \multirow{2}{*}{ 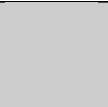 } & \multicolumn{5}{|c|}{ 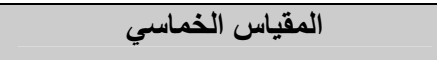 } & \multirow{2}{*}{ السؤل } & \multirow[b]{2}{*}{ المتغيرات } \\
\hline & & 5 & 4 & 3 & 2 & 1 & & \\
\hline 92.9 & 4.31 & - & 2 & 1 & 21 & 18 & 1 & 1. ان تتاح الفرصـة لكافة المساهمين للحصول على تعويض فعال عن انتهاك \\
\hline 90.5 & Tu & 1 & 1 & 2 & 14 & 24 & 2 & 2. معاملة كافة المساهمين حملة نفس النوع من الاسهم معاملة متساوية . \\
\hline 95.2 & 4.50 & - & 1 & 1 & 16 & 24 & 3 & قبل ان يقوموا بالشر اء. \\
\hline 95.2 & 4.50 & - & 1 & 1 & 16 & 24 & 4 & 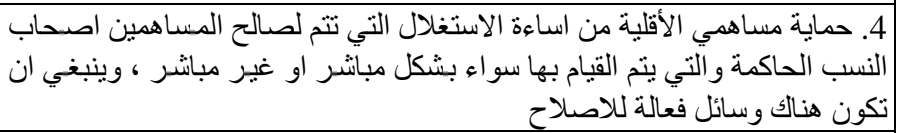 \\
\hline 97.6 & 4.54 & - & - & 1 & 16 & 25 & 5 & المساهمين . . أبون تغيير ات تؤُثر سلباً في حقوق التصويت خاضعة لمو افقة فئات \\
\hline 95.2 & 4.60 & - & 1 & 1 & 12 & 28 & 6 & 6. 6ليها مع المستفيدين من ملكية الاسهر طريق مرشحين لهذا الغرض بطريقة يتم الاتفاق \\
\hline 81.0 & 4.33 & - & 1 & 7 & 11 & 23 & 7 & 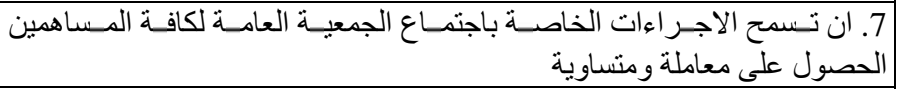 \\
\hline 97.6 & 4.69 & - & - & 1 & 11 & 30 & 0 & 8. الغاء جميع الصعو بات و العو ائق التي تعرقل عملية التصويت عبر الحدود \\
\hline 88.1 & 4.26 & - & 1 & 4 & 20 & 17 & 9 & 9. منع التداول بين المطلعين و التداول الصوري او الثخصي \\
\hline 88.1 & 4.50 & - & - & 5 & 11 & 26 & 10 & 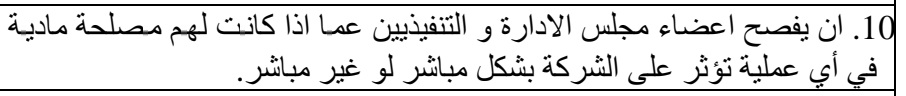 \\
\hline 92.14 & 4.463 & 1 & 1.143 & 2.4 & 14.8 & 23.9 & & المتوسط \\
\hline
\end{tabular}

\section{من الجدول السابق يتبين ما ياتي:-}

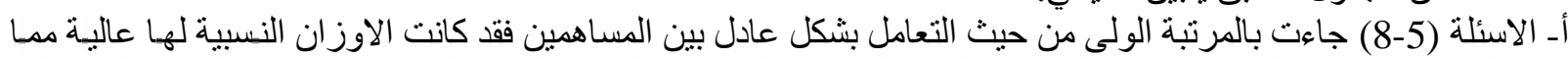

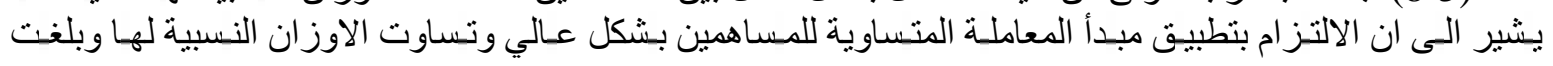

بـ وجاءت الاسئلة (3-4-6) المرتبة الثانية من حيث حماية حقوق المساهمين فقد كانت الاوز ان النئن النسبية لها عالية مما يشير

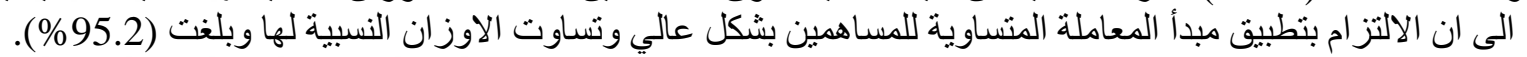

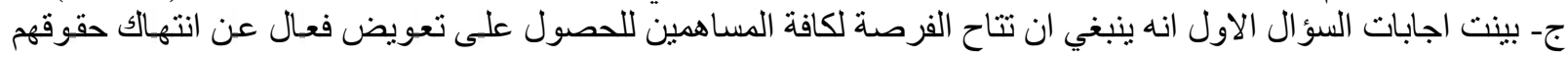

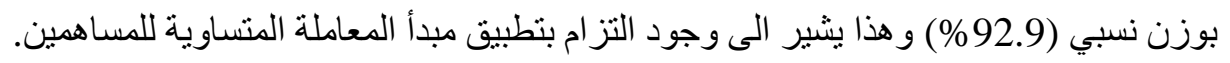

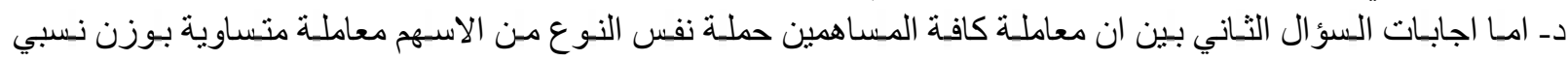

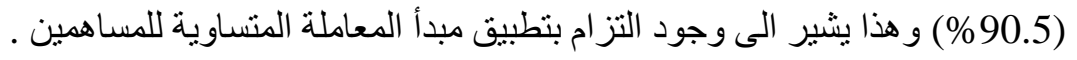

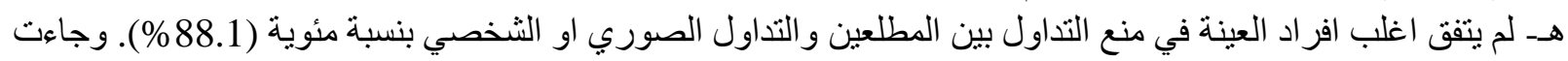

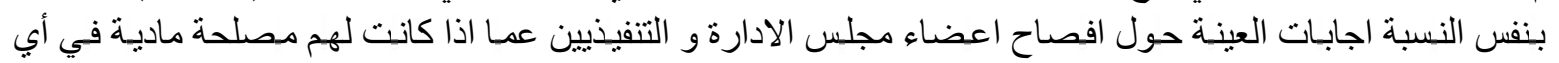

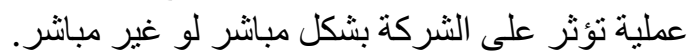

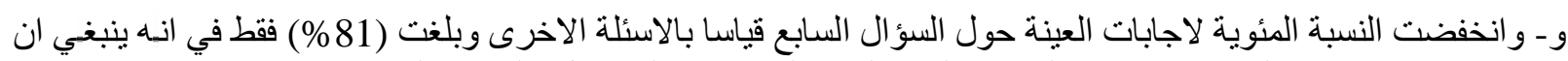

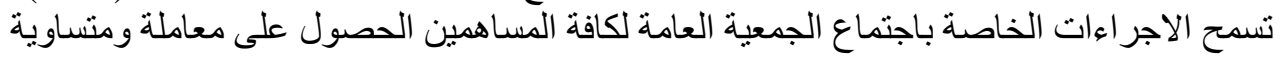

3. تحليل فقر ات دور اصحاب المصالح يعرض (الجدول، 5) نتائج تحليل المحور الثالث من الاستبانة :- 
(1) (11) (11) المهلك (1)

2019 1نسنة
المجلة العراقية

لبهوث السوق ومماية المستنهلك

جدول (5): تحليل فقر ات المحور الثالث/دور اصحاب المصالح

\begin{tabular}{|c|c|c|c|c|c|c|c|c|}
\hline \multirow{2}{*}{ 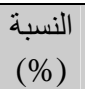 } & \multirow{2}{*}{ 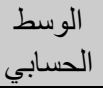 } & \multicolumn{5}{|c|}{ المقياس الخماسي } & \multirow{2}{*}{ 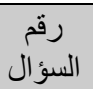 } & \multirow[t]{2}{*}{ مستوى الإجابة } \\
\hline & & 5 & 4 & 3 & 2 & 1 & & \\
\hline 95.2 & 4.48 & - & - & 2 & 18 & 22 & 1 & 1. 1. ان يتم الاعتر اف بحقوق اصحاب الهصالح التي ينشئها القانون او تنشأ نتيجة \\
\hline 92.9 & 4.26 & - & 1 & 2 & 24 & 15 & 2 & 2. الثروة وفرل على العمل ن التعاون النشط بين الثركات واصحاب المصالح في خلق \\
\hline 92.8 & 4.48 & - & 1 & 2 & 15 & 24 & 3 & 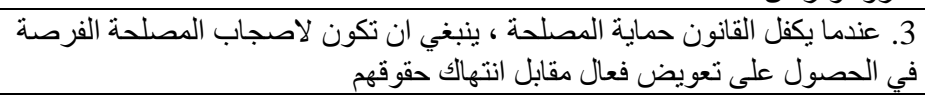 \\
\hline 19.1 & & 4 & 22 & 8 & 7 & 1 & 4 & 4. السماح بوضع اليات لتعزيز الاداء من اجل مشاركة العاملين \\
\hline 83.3 & 4.07 & - & - & 7 & 25 & 10 & 5 & 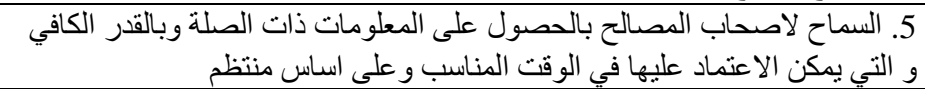 \\
\hline 95.3 & 4.38 & - & - & 2 & 22 & 18 & 6 & 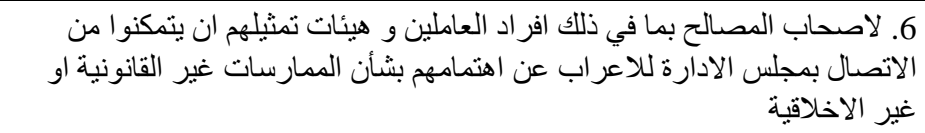 \\
\hline 7.3 & 2.33 & - & 31 & 8 & 3 & - & 7 & 7. عدم الانتقاص او الغض من حقوق اصحاب المصالح اذا ما قامو ابممارسات غير \\
\hline 97.6 & 4.50 & - & - & 1 & 19 & 22 & 8 & 8. تنفيذ حقوق الدائنين اطار حوكمة الثركات باطار فعال وكفء للإعسار و إطار فعال اخر \\
\hline 94.2 & 4.55 & - & 1 & 1 & 14 & 26 & 9 & 9. يتم الاتصال مع اصحاب الدصالح لايجاد طرق مختلفة لتأمين تدفق رأس المال \\
\hline 90.5 & 4.36 & - & 1 & 3 & 18 & 20 & 10 & الثركة وجود الية عمل فعالة بين اصحاب المصالح ومجلس الادارة لتوفير استمر ارية \\
\hline 76.82 & 3.991 & 4 & 9.5 & 3.6 & 16.5 & 17.6 & & المنوسط \\
\hline
\end{tabular}

يبين (الجدول، 5) نتائج تحليل المحور الثالث (دور اصحاب المصالح)، ومنه ينتين الاتي:

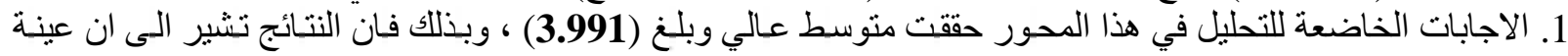

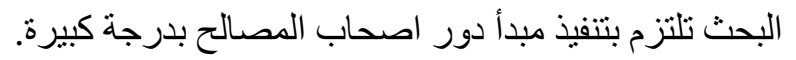

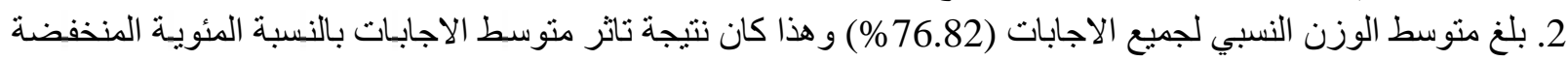

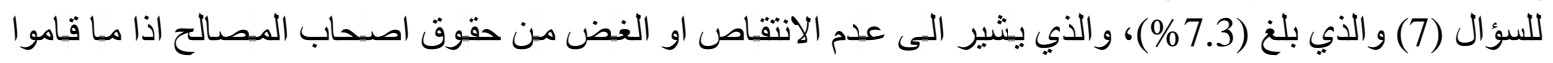

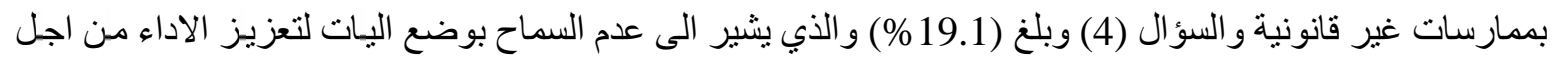
مشاركة العاملين.

3. تراوح الوزن النسبي لاجابات اسئلة المحور بين اعلى وزن نسبي وبلغ (97.6\%) للسؤ ال الثامن، و ادنى وزن نسبي بلغ

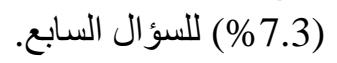

4. اتفق اغلب افر اد العينة على امكانية اصحاب المصالح بما في ذللك افر اد العاملين و هيئات تمثيلهج ان يتمكنو الهن الاتصـال

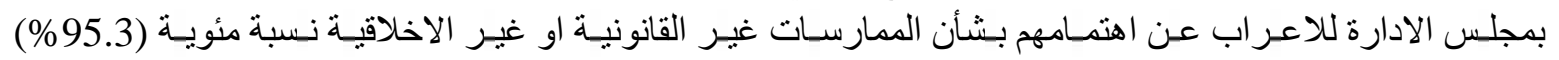

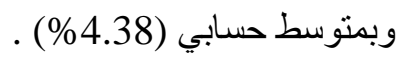

5. اتفق اغلب افر اد العينة على ان يتم الاعتر اف بحقوق اصحاب المصالح التي ينشئها القانون او تنشأ نتيجة لاتفاق مبادلة

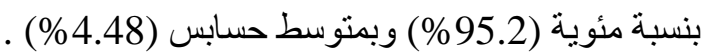

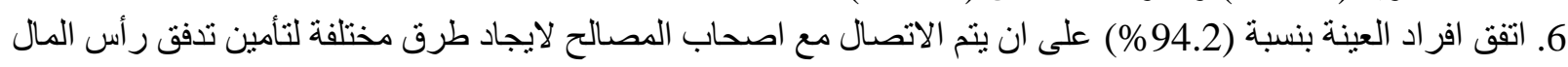
الخارجي و الداخلي للثركة وبمنو سط حسابي (4.55).

\section{Analysis of second pillar issues / disclosure and transparency}

\section{ثالثا: تحليل فقر ات المحور الثافي/ الافصاح والشفافية}

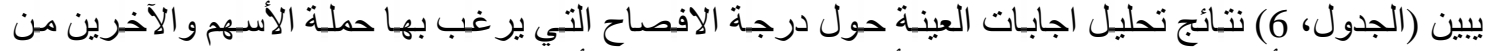

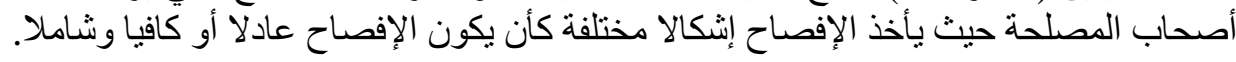




\section{المجلد (11) العدد (1) (1)}

2019 السنة
المجاة العراقية

لبهوث السوق وهماية المستملك

جدول (6): تحليل فقر ات المحور الرابع/ الافصاح والثفافية

\begin{tabular}{|c|c|c|c|c|c|c|c|c|}
\hline \multirow{2}{*}{ 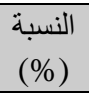 } & \multirow{2}{*}{ الوسطي } & \multicolumn{5}{|c|}{ المقباس الخماسي } & \multirow{2}{*}{ 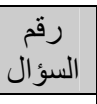 } & \multirow[t]{2}{*}{ مستوى الإجابة } \\
\hline & & 5 & 4 & 3 & 2 & 1 & & \\
\hline 95.2 & 4.38 & - & - & 2 & 22 & 18 & 1 & 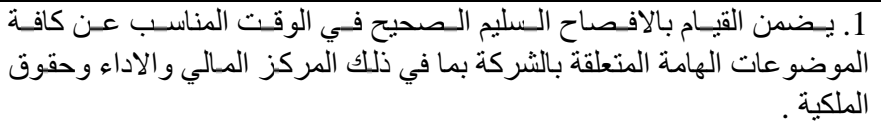 \\
\hline 92.9 & 4.67 & - & 1 & 2 & 7 & 32 & 2 & و الافصاح المالي و غير المالي احساح عنها طبقاً للمستويات النو عية المرتفعة للمحاسبة \\
\hline 92.9 & 4.31 & - & 1 & 2 & 22 & 17 & 4 & 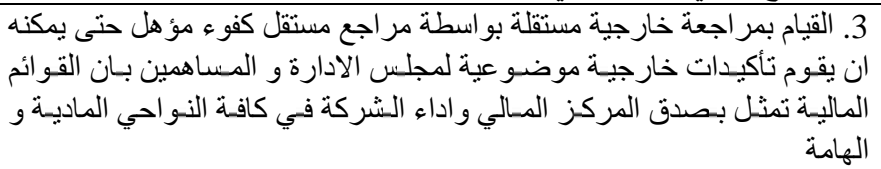 \\
\hline 83.3 & 4.02 & - & 1 & 6 & 26 & 9 & 4 & 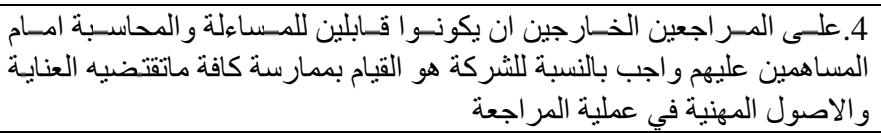 \\
\hline 92.9 & 4.48 & - & 3 & - & 15 & 24 & 5 & 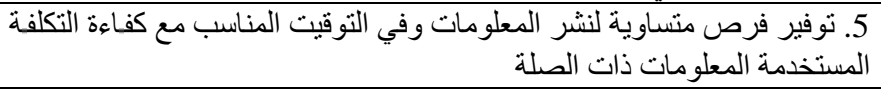 \\
\hline 76.2 & 4.05 & - & 1 & 9 & 19 & 13 & 6 & 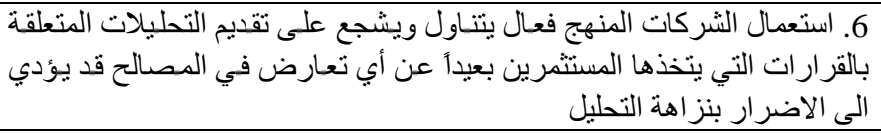 \\
\hline 90.5 & 4.38 & - & - & 4 & 18 & 20 & 7 & 7.ان يتضمو حقوق الافصوياح النتائج المالية ونتائج عمليات الشركة والافصاح ملكية \\
\hline 85.7 & 4.19 & - & 2 & 4 & 20 & 16 & 8 & 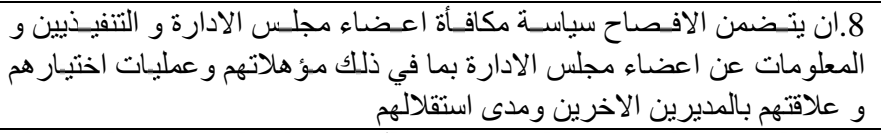 \\
\hline 90.5 & 4.36 & - & 2 & 2 & 17 & 21 & 9 & 9. ن ينضمن الأفتصة احساح العمليات المتصلة بأطراف من الشركة وجميع عوامل \\
\hline 95.2 & 4.43 & - & - & 2 & 20 & 20 & 10 & 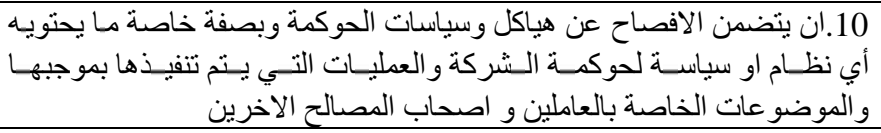 \\
\hline 89.53 & 4.327 & & 1.57 & 3.67 & 18.6 & 19 & & المتوسط \\
\hline
\end{tabular}

يلاحظ من النتائج المستحصل عليها من (الجدول، 6) ما يأتي:

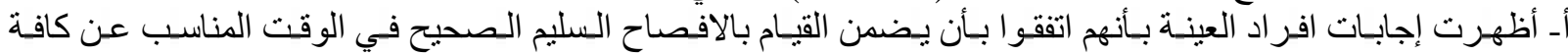

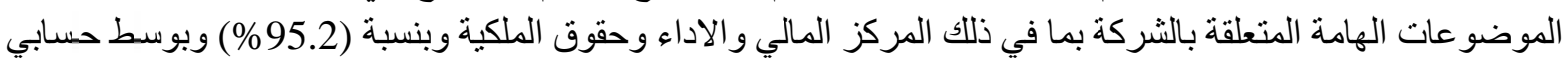

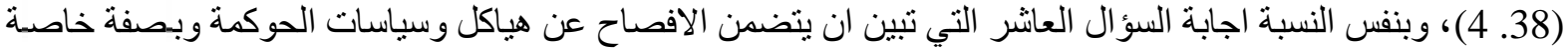

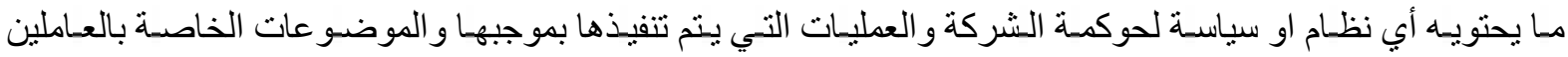
و اصحاب المصالح الاخرين وبوسط حسابي (4.43).

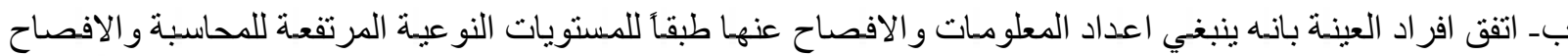

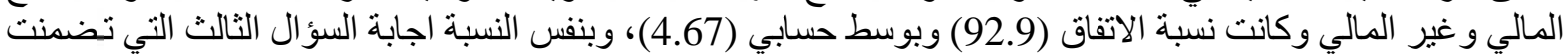

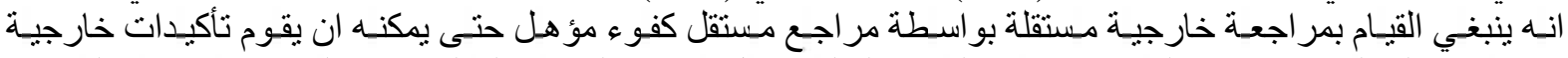

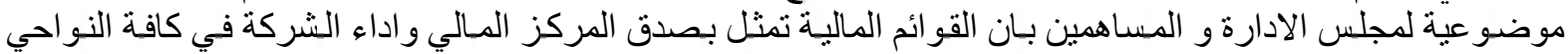

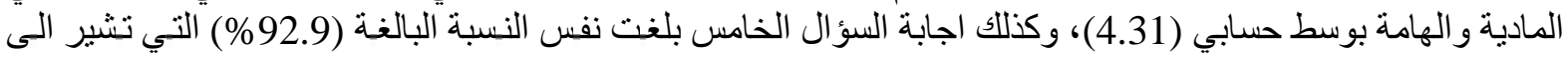

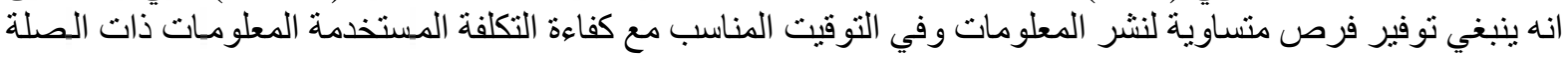

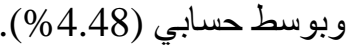

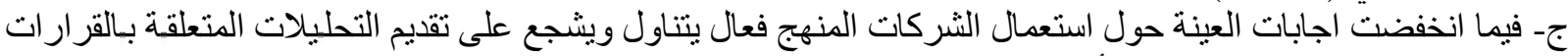

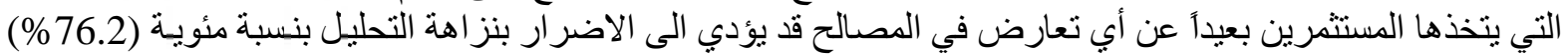

$$
\text { وبوسط حسابي (4.05). }
$$




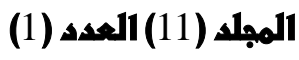

2019 1نسنة
المهاة العراقية

لبهوث السوق ومماية المستنهلك

دـ اتفق افر اد العينة بنسبة (85.7\%) على ان يتضمن الافصاح سياسة مكافأة اعضاء مجلس الادارة و التنفيذيين و المعلومات

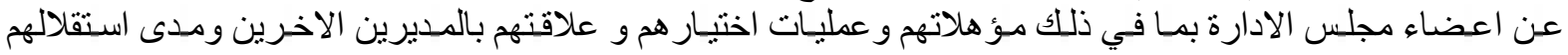
وبوسط حسابي (4.19).

\section{المبهث الرابع \\ Conclusions and Recommendations الاستتاجات و التوصيات}

أولاً: الاستنتاجلت Conclusions 1. أنآ: الثركات تقوم بحماية مساهمي الأقلية من اساءة الاستغلال التي تتم لصالح المساهمين اصحاب النسب الحاكمة والتي

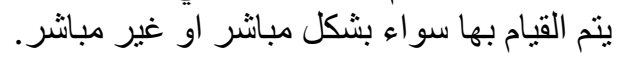

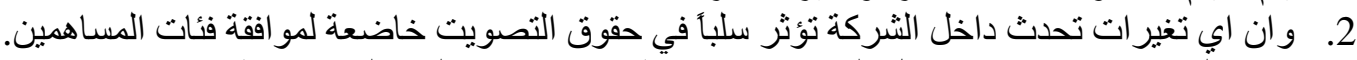

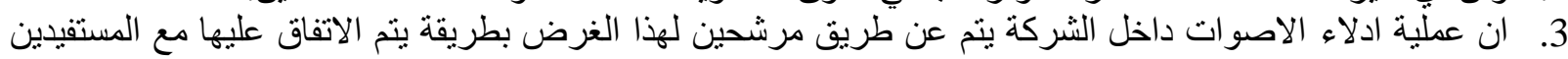

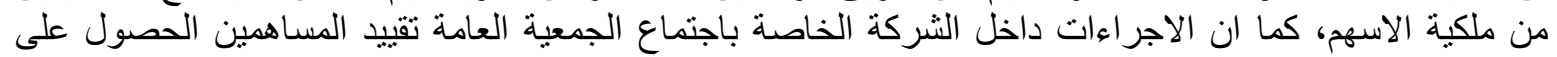
معاملة متساوية.

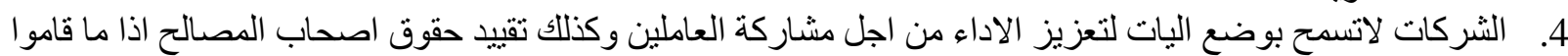

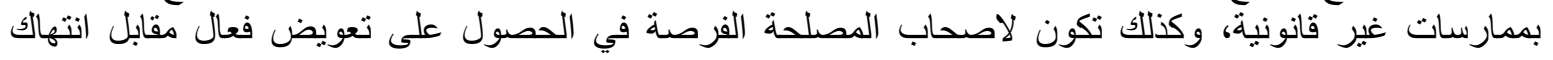
حقوقهم. 5. يساهم الالتز ام بالافصاح الكافي في وضع اساليب رقابية تمنع اي طرف من الاطر اف ذات العلاقة بالمنشأة داخليا او

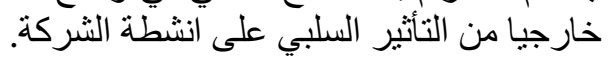

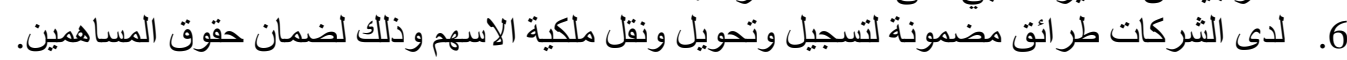

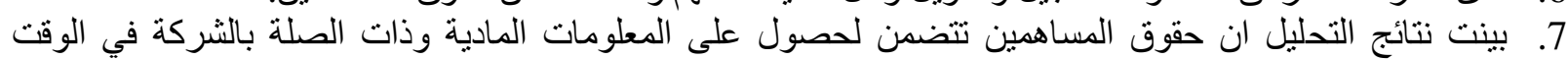

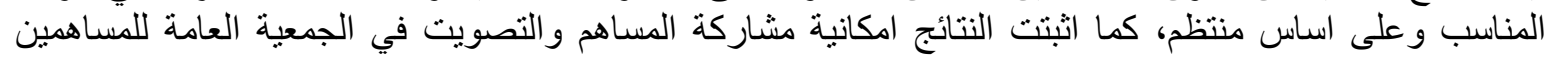

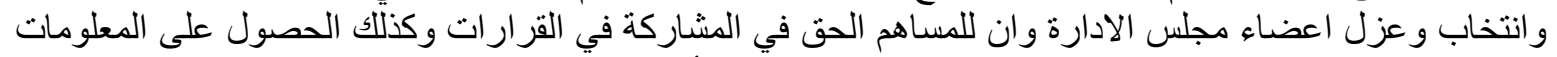

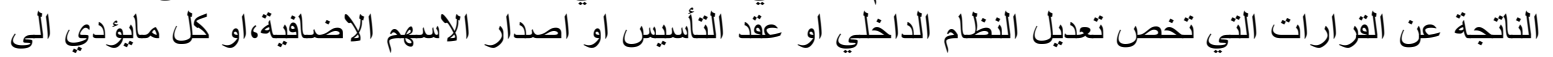

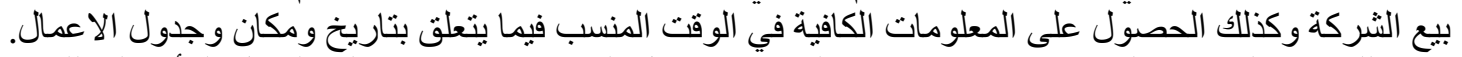

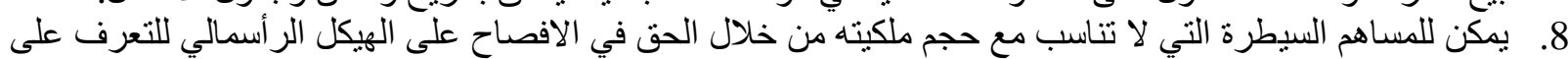

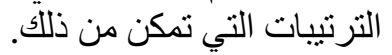

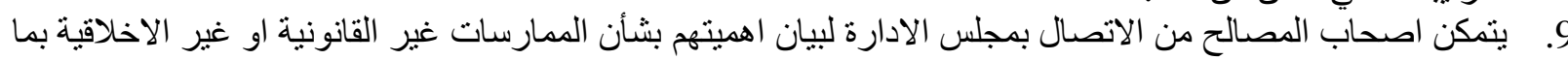
في ذلك افر اد العاملين و هيئات تمثيلهم.

ثنانياً: التوصيات Recommendations

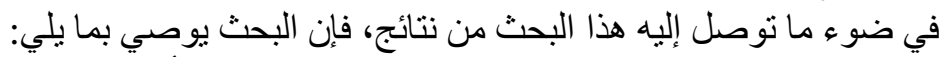

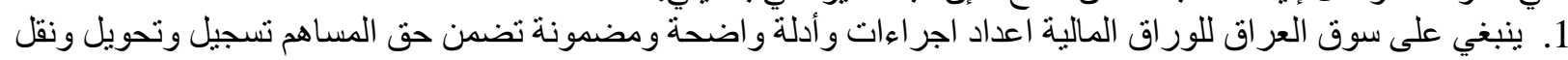
ملكية الاسهر. 2. ينبخي على الثركات المساهمة في سوق العر اق للاور اق المالية تمكين المساهمين في الحصول على المعلومات الخاصة

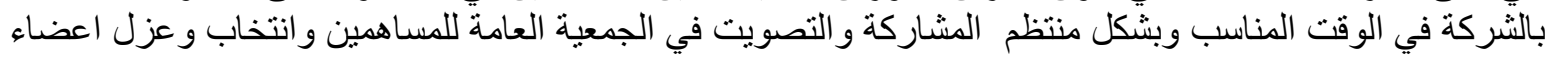

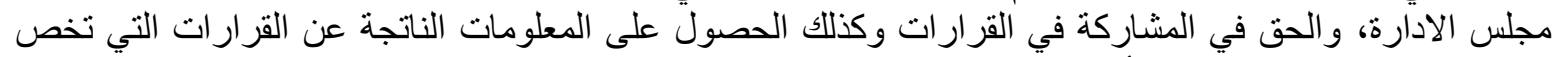

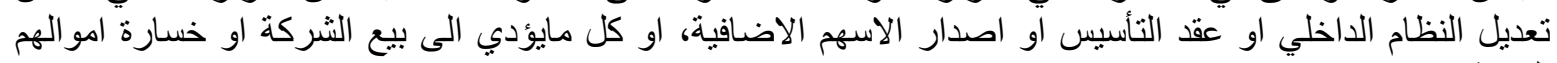
المستثمرة فيها. 3. ضــرورة الز ام الشركات المدرجـة في سـوق العراق للاور اق المالية باعداد التقارير الماليـة الفصلية و النصف سـوية بالاضافة التى التقارير السنوية. 4. ضرورة تبني سـوق العراق للاور اق المالية لو ائح تنظيمية وقانونية لتطبيق الافصـاح المحاسبي للشركات، وذلك لكون

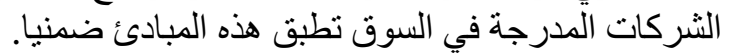

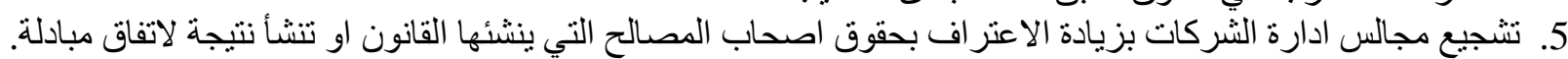

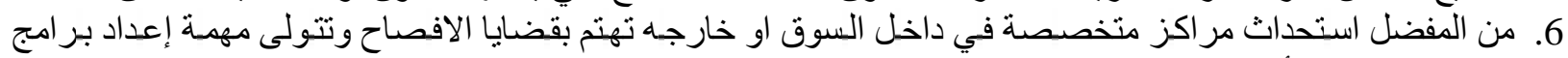
تدرييية لترسيخ أهدافه ومتطلباتها. 


\section{المجلد (11) العدد (1) (1)}

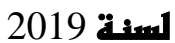

7.ضرورة مرجعة القو انين و الانظمة والتعليمات ذات الصلة بنظام المعلومات المحاسبية واقتر اح بعض التغير ات ات بما ينسجم مع حوكمة الثركات و الياتها مثل قانون الثركات رقم (21) لسنة 1997 المعدل و القانون المؤقت للاسو اق المالية رقم

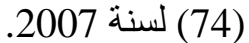

8.الزام الثركات المدرجة في سوق العراق المالية بتنفيذ مبدأ دور اصحاب المصالح بدرجة كبيرة وذللك من خلال عدم

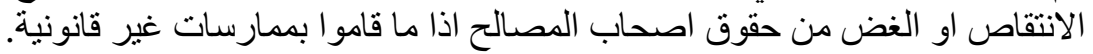

REFERENCES المصادر

I. Abeywardana, N. \& Panditharathna, K. (2016). The extent and determinants of voluntary disclosures in annual reports: evidence from banking and finance companies in Sri Lanka. Accounting and Finance Research, 5(4), 147-166.

II. Abu Alatta, N. (2003). Corporate Governance: A Way Forward with Highlighting the Egyptian Experience. Center for International Private Enterprise.

III. Ahmed, R. A. (2008). The role of corporate governance in determining the fair price of stocks in the stock market-analytical study. Journal of the Faculty of Commerce for Scientific Research, 1(45), 22-38.

IV. Alaker, M. B. J. (2010). The Effect of Accounting Disclosure in the Financial Statements Published on the Implications of the Financial Crisis in the Jordanian Banking Sector. Master Thesis, Business School, Middle East University.

V. Alhayali, W. N. (2007). Accounting Theory. Publications of the Arab Open Academy in Denmark.

VI. Alzubaidi, H. M. (2000). Banking Management and the Strategy of Depositing Deposits and Credit Provision. Al-Warraq Foundation, Amman.

VII. Choi, F. D. S. (1972). Financial disclosure and entry to the european capital market. Journal of Accounting Research, 11(2), 159-175.

VIII. Dahmash, N. \& Abu Zer, A. I. (2003). Improving and Developing Institutional Governance in Banks. Journal of Banks in Jordan, 10 (II), December.

IX. Frederick, C., Carol, A. F. \& Gary, M. (2004). International Accounting. Arabization A. Dr. Mohammed Essam Al-Din, Dar Al-Marikh Publishing, Saudi Arabia.

X. Gamal El Din, A. (2006). Corporate Governance: Key Concepts and Public Framework in Egypt: Transparency and Disclosure. Towards a Better Climate for Investment in Arab Countries, Cairo: Egyptian Directors' Center, Ministry of Investment.

XI. Gassman, G. (2002). Opening Remarks Before the Symposium on Enhancing Financial Transparency. U.S. Securities and Exchange Commission, Washington, D.C, June.

XII. Gruszczynski, M. (2006). Corporate governance and financial performance of companies in Poland. International Advances in Economic Research, 12(2), 251259.

XIII. Gyan, C. (1974). A study of the consensus on disclosure among public accounting and security analysis. The Accounting Review, 49(4), 733-742.

XIV. Hammad, T. (2005). Corporate Governance Concepts - Principles - Experiences Governance Applications in Banks. Egypt: University House.

XV. Hendriksen, E. \& Vem Breda, M. (1995). Accounting Theory. $5^{\text {th }}$ edition, Southern Methodist Unniversity.

XVI. Hendriksen, E. \& Breda, M. (2001). Accounting Theory. Mcgraw Hill, Singapore.

XVII. IMF Policy Development and Review Department. (1999). Progress Report. Developing International Standards. 
XVIII. Jiangli, W. H. U. \& Yom, C. (2004). Relationship Lending, Accounting Disclosure and Credit Availability During Crisis. Federal Deposit Insurance Corporation, Washington, DC.

XIX. Khoury, N. S. (2003). The Accounting Profession between Financial Impairment and Corporate Governance in Companies. Bayan Newspaper, May, United Arab Emirates.

XX. Kim, W., Black .B. S. \& Jang, H. (2006). Dose corporate governance predict firms market values? Evidence from Korea. Journal of Law, Economics and Organization, 22(2), 1-14.

XXI. Kopeikina, L. (2006). The Elements of Aclear Decision. Mitsloan- Management Review, Vol 47.

XXII. Magdy, M. S. (2009). The role of audit committees in corporate governance and its impact on the quality of financial statements published in the Egyptian business environment. Journal of the Faculty of Commerce for Scientific Research, 2, 23-34.

XXIII. Makhlouf, A. (2009). The Global Financial Crisis and the Prospects of the Solution Using Principles of Disclosure, Transparency and Corporate Governance. A Presentation at The International Scientific Forum.

XXIV. OECD. (1999). Principles of Corporate Governance. Organization for Economic Cooperation and Development Publications Service.

XXV. OECD. (2001). Transparency and Disclosure. $2^{\text {nd }}$ meeting of the Eurasan Corporat Governance Round table, Toilisi-Georgia, 7-8 June.

XXVI. Saidi, N. (2005). Corporate Governance in the Arab Country: role of the Banking System in Ensuring Transparency and Disclosure. Forum on Corporate Governance in Banks and Financial Institutions.

XXVII. Sahnoun, G. (2008). Conditions for the Rise of Financial Markets, Comparative Study of the Countries of Egypt, Tunisia and Algeria. Thesis for the $\mathrm{PhD}$ in Economics, Finance and Finance, University of Algiers.

XXVIII. Shleifer, V. R. (1997). A survey of corporate governance. Journal of Finance, 52(2), 737-783.

XXIX. Shousha, A. A. A. (2009). The Effect of Corporate Governance on its Financial Performance. An Empirical Study on Companies Listed on the Egyptian Stock Exchange.

XXX. Sulaiman, M. M. (2006) Corporate Governance and the Treatment of Financial and Administrative Corruption, Comparative Study. University House, Egypt.

XXXI. Sweiti, I. M. \& Attayah, O. F. (2013). Critical Factors Influencing Voluntary Disclosure: The Palestine Exchange "PEX". Global Journal of Management and Business Research, 13(6), 1-9.

XXXII. Turki, M. I. A. (1989). Measuring the Validity of Reading and Understanding Financial Reports of Saudi Joint Stock Companies. College of Administrative Sciences, King Saud University.

XXXIII. Xiaochuan, Z. (2004). Improve Corporate Governance \& Develop Capital Market. At the Euro Money China Forum, Beijing, China, Dec.

XXXIV. Ziyud, L. (2007). The Role of Accounting Disclosure in the Stock Market in Rationalizing the Investment Decision. Tishreen University Journal for Studies and Scientific Research, Series of Economic and Legal Sciences.

XXXV. Zouina, B. (2014). Economic and Management Sciences. University of Mohamed Boudiaf, Algeria. 


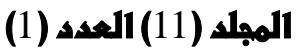

المهلة العراقية

لبهوث السوق ومماية المستنهلك

\section{الملاحق appendixs}

$$
\text { مضرق المجيب المحترم: البيان البحث تحية طيبة }
$$

تقوم الباحثتان بإجر اء بحث بعنوان "دور حوكمة الثركات في توفير الحماية المطلوبـة لحقوق المستثمرين: دراسـة

تحليلية في سوق العر اق للاور اقن المالية" .

نرجو من حضرتكم التكرم بالمساعدة في إتمام هذه البحث عن طريق الإنهابة على الإنى الأسئلة التي تتضمنها الإستبانة

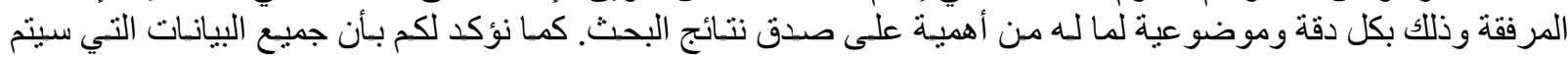

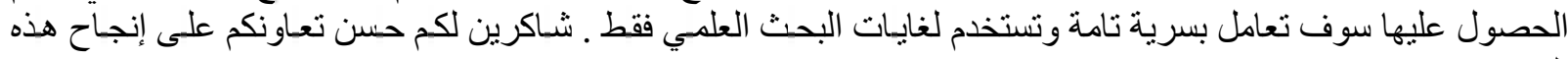

الباحثنان

وتفضلوا بقبول فائق الإحتر ام و التقدير

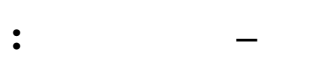

ضع علامة ( ) في الحقل الذي يمثل الأجابة التي تناسب مع وجهة نظرك ـ

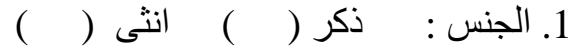

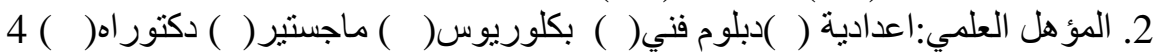

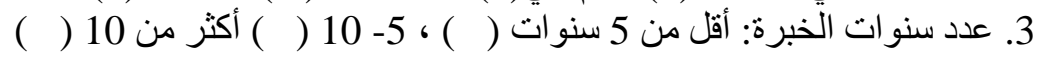

4. القطاع الذي تنتمي اليه الثركة المستثمر فيها: المصارف( ) الصناعي ( ) الخدمي( ) الاستثمار( ) السياحة

$$
\text { ثانيا - أسئلة وفقرات الإستبيان }
$$

\begin{tabular}{|c|c|c|c|c|c|}
\hline \multicolumn{5}{|c|}{ المقياس الخماسي } & \multirow[t]{2}{*}{ مستوى الإجابة } \\
\hline 5 & 4 & 3 & 2 & 1 & \\
\hline \multicolumn{6}{|r|}{ فقرات المحور الاول / حماية حقوق المساهمين } \\
\hline & & & & & 1. ت تتضمن الحقوق الاساسية للمساهمين طر ائق مضمونة لتسجيل وتحويل و نقل ملكية الاسهم \\
\hline & & & & & 2. استضمن مقتظق. المساهمين الحصول على المعلومات المادية وذات الصلة بالثركة في الوقت المناسب وعلى \\
\hline & & & & & 3. يمكن للمساهم المشاركة و التصويت في الجمعية العامة للمساهمين و انتخاب و عزل اعضاء مجلس الادارة . . \\
\hline & & & & & 4. ل للمساهم نصيب من ارباح الثركة . \\
\hline & & & & & 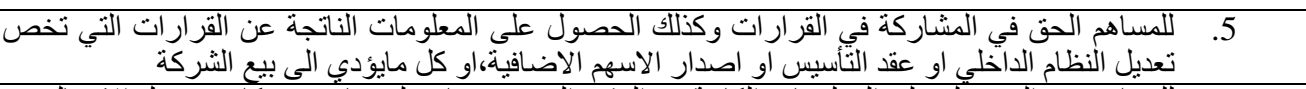 \\
\hline & & & & & 6. للمساهم حق الحصول على المعلومات الكافية في الوقت المنسب فيما يتعلق بتاريخ ومكان وجدول الاعمال . \\
\hline & & & & & 7. للمساهم الحق في مسألة مجلس الادارة حول استخدام الوسائل المضادة للاستيلاء على الثركة \\
\hline & & & & & 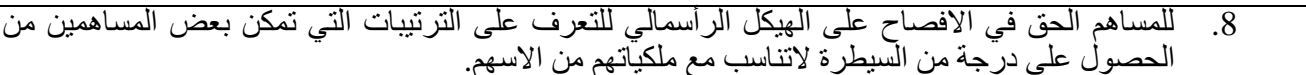 \\
\hline & & & & & 9. اللثخساهم الحق بالتصويت بالحضور شخصياً او غيابياً مع مر اعاة الدساو اة في تأثيّر التصويت سواء بالحضور \\
\hline & & & & & 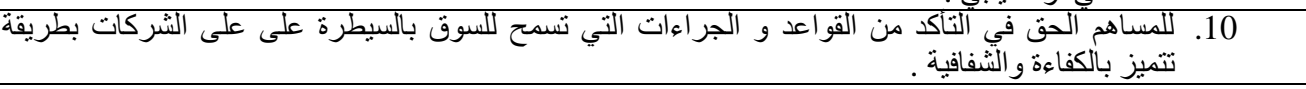 \\
\hline
\end{tabular}




\section{المهلى (11) العده (1)}

السنة 2019
المهلة العراقية

لبهوث السوق ومماية المستمهلك

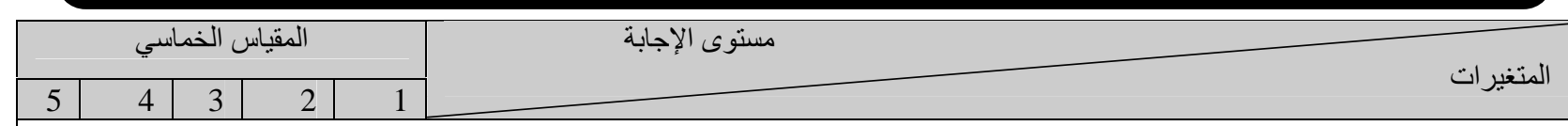

فقرات المحور الثاني / المعاملة المتساوية للمساهمين

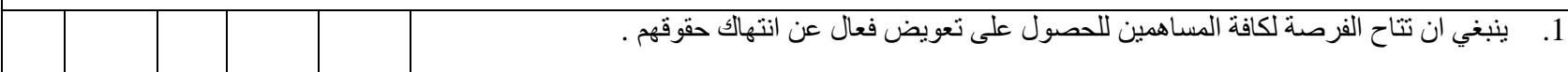
2.

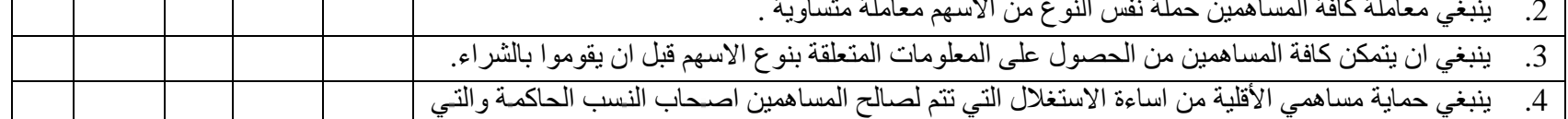

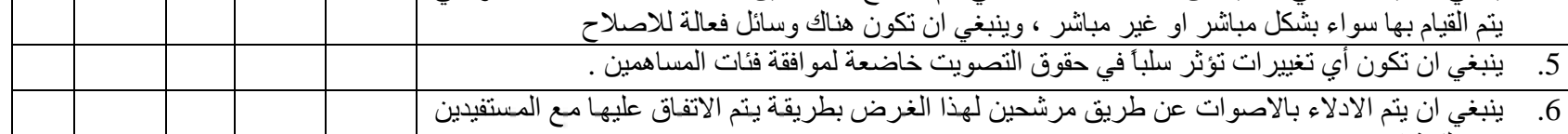

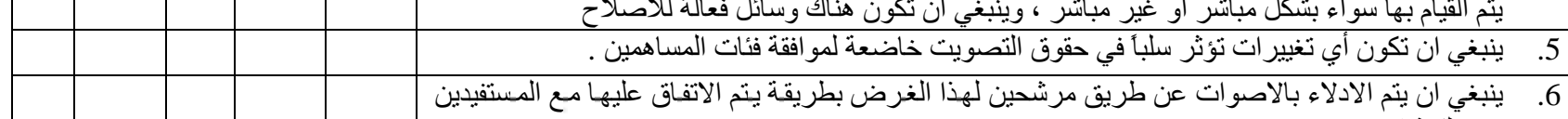

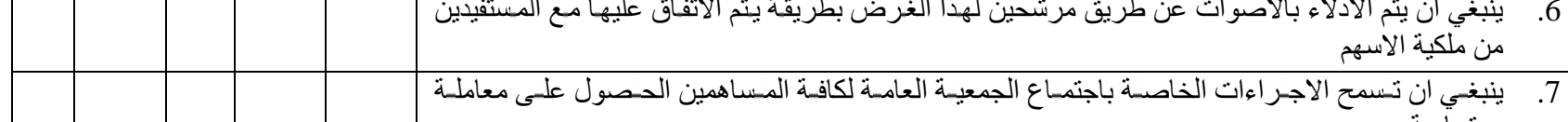

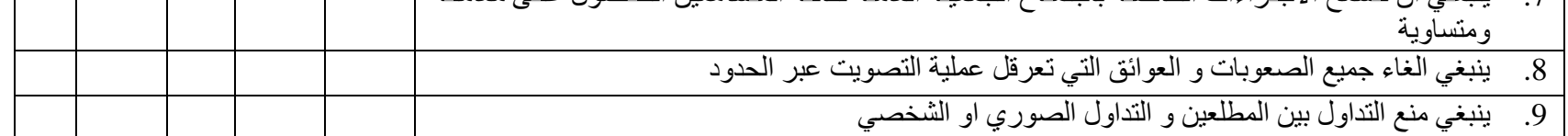

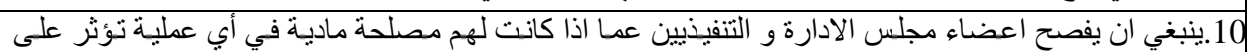

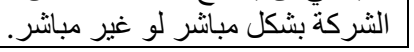

\begin{tabular}{|c|c|c|c|c|c|}
\hline \multicolumn{5}{|c|}{ المقياس الخماسي الخي } & \multirow[b]{2}{*}{ 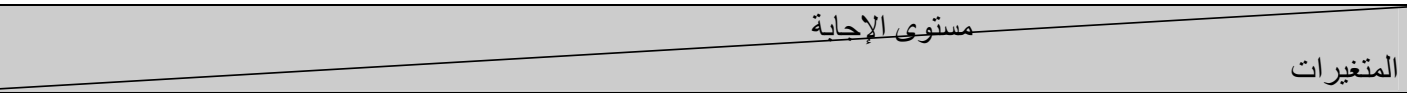 } \\
\hline 5 & 4 & 3 & 2 & 1 & \\
\hline \multicolumn{6}{|r|}{ فقر ات المحور الثالث/ دور اصحاب المصالح } \\
\hline & & & & & 1. ينبغي ان ينم الاعتر اف بحقوق اصحاب المصالح التي ينشئها القانون او تتشأ نتيجة لاتفاق مبادلة. \\
\hline & & & & & 2. العمل على التعاون التعاون النشط بين الثركات و اصحاب المصالح في خلق الثروة وفرص العمل \\
\hline & & & & & 3. عندما يكفل القانون حماية المصلحة ، ينبغي ان تكون لاصجاب المصلحة الفرصة في الحصول على تعويض فعال مقابل \\
\hline & & & & & 4. ينبغي السماح بوضع اليات لتعزيز الاداء من اجل مشاركة العاملين \\
\hline & & & & & 5. ينبغي السماح لاصحاب المصالح بالحصول على المعلومات ذات الصلة وبالقدر الكافي و التي يمكن الاعتماد عليها في الوقت \\
\hline & & & & & 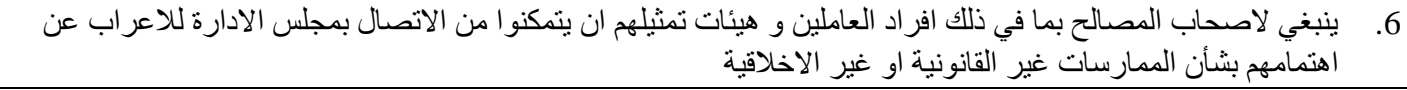 \\
\hline & & & & & 7. ينبغي عدم الانتقاص او الغض من حقوق اصحاب المصالح اذا ما قامو ا بممارسات غير قانونية \\
\hline & & & & & 8. ينبغي ان يستكمل اطار حوكمة الثركات باطار فعال وكفء للإعسار و إطار فعال اخر لتنفيذ حقوق الدائنين \\
\hline & & & & & 9. يتم الاتصال مع اصحاب المصالح لايجاد طرق مختلفة لتأمين تدفق رأس المال الخارجي و الداخلي للشركة \\
\hline & & & & & 10.وجود الية عمل فعالة بين اصحاب المصالح ومجلس الادارة لتوفير استمر ارية الثركة \\
\hline
\end{tabular}

\begin{tabular}{|c|c|c|c|c|c|}
\hline \multicolumn{2}{|c|}{} & \\
\hline 5 & 4 & 2 & \\
\hline
\end{tabular}




\section{المهلى (11) العده (1)}

2019 1.بنـ

\section{المجلة العراقية}

لبهوث السوق ومماية المستمهك

\begin{tabular}{|c|c|c|c|c|c|}
\hline \multicolumn{5}{|c|}{ المقياس الخماسي } & \multirow[b]{2}{*}{ 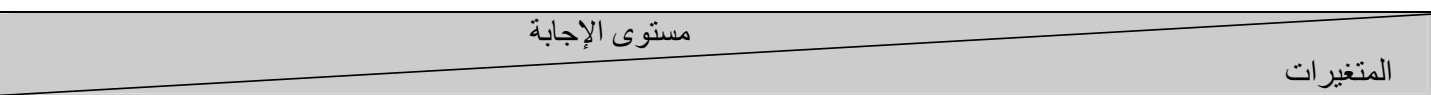 } \\
\hline 5 & 4 & 3 & 2 & 1 & \\
\hline & & & & & 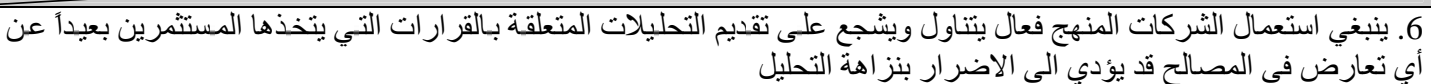 \\
\hline & & & & & 7. ينبغي ان يتضنمن الافصاح النتائج المالية ونتائج عمليات الشركة والافصاح ملكية الاسهم وحقوق التصويت \\
\hline & & & & & 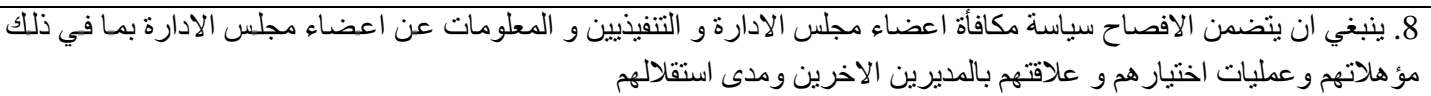 \\
\hline & & & & & 9. ينبغي ان بتضمن الافصاح العمليات المتصلة بأطر اف من الشركة وجميع عو امل المخاطرة المتوقعة \\
\hline & & & & & 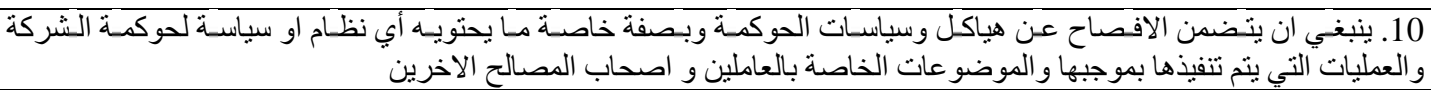 \\
\hline
\end{tabular}

\begin{tabular}{|c|c|c|}
\hline الموقع & الاسم & ت \\
\hline الكلية التقنية الادارية بغداد & أ.م.د. صلاح الديم حمح امين & 1 \\
\hline الكلية التقنية الادارية بغداد & أ.م.د. رائد مجيد عبد & 2 \\
\hline الكلية التقنية الادارية بغداد & أ.م.د. سهاد صبيح فرج & 3 \\
\hline الكلية التقنية الادارية بغداد & أ.م.د. فيان عبد الرحمن & 4 \\
\hline الكلية التقنية الادارية بغداد & م.د. سهر حسن حسين & 5 \\
\hline الكلية التقنية الادارية بغداد & م.د. حمح عبد حمح & 6 \\
\hline
\end{tabular}

